\title{
Signal-Transducing G Proteins and Antidepressant Drugs: Evidence for Modulation of $\alpha$ Subunit Gene Expression in Rat Brain
}

\section{Klaus-Peter Lesch and Husseini K. Manji}

Signal-transducing $G$ proteins, heterotrimers formed of $\alpha, \beta$, and $\gamma$ subunits, are central to the coordination of receptor-efector communication. They are derived from a large gene family, and recent cloning and sequencing of $c D N A$ s encoding the $\alpha$ subunits, which confer receptor and effector specificity on the heterotrimer, have defined four major classes, $G_{s}$, $G_{i}, G_{q}$, and $G_{12}$, with at least 16 isotypes. The $G$ proteins that coordinate receptor-effector activity are especially important in the central nervous system (CNS), where they serve widespread, critical roles in the regulation of neuronal function, maintain the functional balance between neurotransmitter systems, and, as such, represent attractive potential targets for antidepressant drugs. We describe an integrated series of animal and cell culture studies aimed at testing the hypothesis that alterations in $G$ protein function may contribute the complex neuroadaptive mechanisms involved in the clinical actions of antidepressants, and demonstrate that long-term adninistration of a wide spectrum of antidepressant drugs regulate $G \alpha_{s}, G \alpha_{i 1}, G \alpha_{i 2}, G \alpha_{o}, G \alpha_{q}$, and $G \alpha_{12} m R N A$ and protein expression in various areas of the rat brain. Additionally, we present the polymerase chain reaction- $(P C R)$ mediated cross-species partial cDNA cloning and sequencing of rat and human $G \alpha_{o}$ and rat $G \alpha_{12}$, illustrate the regional distribution of $G \alpha m R N A$ and protein in rat brain, and provide evidence that different classes of antidepressants alter expression and/or stability of the recently identified $G \alpha_{12}$ mRNA. We conclude that long-term treatment with antidepressant drugs exerts differential effects on $G \alpha m R N A$ and protein expression in rat brain, thus modifying signal transduction as an integral part of complex neuroadaptive mechanisms that may underlie their therapeutic efficacy. The development of novel drugs with $G$ proteins as primary targets remains an attractive prospect for the future.

Psychopharmacologic research has traditionally focused on the effects of antidepressant drugs on individual neurotransmitters, and a variety of acute biochemical effects have been observed. Paralleling the recognition of the typically weeks-long latency to clinical response studies of antidepressant treatment actions have moved from a focus on disparate acute effects to an interest in possible common chronic changes. Thus, in recent years,

From the Section of Neuropharmacology, Laboratory of Clinical Science and Section on Clinical Pharmacology, Experimental Therapeutics Branch, National Institute of Mental Health, Bethesda, Maryland.

Address reprint request to K.P. Lesch, M.D., Department of Psychiatry, Fuechsleinstr. 15, 8700 Wuerzburg, Germany.

Recipient of A. E. BENNETT AWARD for 1992.

Received May 15, 1992. 
research has focused upon the effects of chronic administration of antidepressants (ADs) on various aspects of neuronal function, with a wealth of studies demonstrating alterations in the density and/or sensitivity of several neurotransmitter receptor systems. Although there is considerable conflicting evidence regarding the effects on noradrenergic, serotonergic, dopaminergic, muscarinic, GABAergic, and opioidergic receptor systems (likely due to differences in route of application, duration of treatment, functional paradigm, receptor subtypes, and pre- vs postsynaptic localization) (Sugrue 1983), chronic administration of a variety of antidepressants [including tricyclics (TCAs), monoamine oxidase inhibitors (MAOIs), and "atypical ADs"] appear to downregulate or desensitize the $\beta$ adrenergic and serotonin 2 (5-HT $)$ receptors in rat forebrain (Sulser 1984) and enhance the synaptic efficacy of serotonergic neurotransmission via the 5-HT $\mathrm{T}_{1 \mathrm{~A}}$ receptor in rat hippocampus (Blier et al 1990; Chaput et al 1991). Even these effects, however, do not fully explain the clinical efficacy of all antidepressants, and the dissociation between receptor number and their functional responsiveness has led to the investigation of possible postreceptor sites of actions of these drugs. Neurotransmitter function may be altered indirectly through the regulation of intracellular signaling, and antidepressant agents may be effective not because they are "noradrenergic" or "serotonergic" agents per se, but because they modulate converging postsynaptic signals generated in response to multiple endogenous neurotransmitters, including norepinephrine (NE) and 5-HT. In this context, the signal-transducing $G$ proteins, which play a major role in the amplification and integration of signals in the central nervous system (CNS), are in a unique position to affect the functional balance between neurotransmitter systems, and, as such, represent attractive potential targets for antidepressant drug effects.

$G$ proteins are heterotrimeric ( $\alpha, \beta$, and $\gamma$ subunits) guanine nucleotide- (GTP) binding proteins that serve as "molecular switches" for receptor-generated signal transduction and convey information from cell surface receptors to various effectors, including adenylyl cyclase, phospholipase $c$, ion channels, and cyclic GMP phosphodiesterase (Bimbaumer 1990; Houslay and Milligan 1990); Taylor 1990; Moss and Vaughan 1991). The $\alpha$ subunit, which is generally thought to confer receptor and effector specificity on the $\mathbf{G}$ protein, contains the GTP-binding (and hydrolysing) site, whereas the $\beta$ and $\nu$ subunits appear, at least to some degree, to be interchangeable. The $\mathbf{G}$ proteins that coordinate receptoreffector activity are derived from a large gene family, and recent cloning and sequencing of cDNAs encoding the $\alpha$ subunits have defined four major classes, $G_{s}, G_{i}, G_{q}$, and $G_{12}$, with at least 16 isotypes (Simon et al 1991). The $\mathrm{G}$ protein cycle, at the center of receptoreffector communication, represents the unique compromise of a carefully timed molecular switch, allowing the cell to respond both rapidly and to low-stimulus concentration (Gilman 1989). Although $G$ proteins are present in all eukaryotic cells and control various metabolic, humoral, and developmental functions, they are especially important in the CNS, where they serve the critical roles of first amplifying and "weighting" extracellularly generated neuronal signals and then transmitting these integrated signals to effectors, thereby forming the basis for a complex information processing network (Ross 1989; Manji 1992). Thus, given their widespread, critical roles in the regulation of neuronal function, it is not surprising that recent research has begun to focus upon the elucidation of the role of $G$ proteins in the etiology and pathophysiology of various psychiatric disorders and their treatments (Avissar et al 1988, Avissar and Schreiber 1989, 1992; Lesch and Lerer 1991; Manji 1992; and references therein).

In the present report, we describe an integrated series of animal and cell culture studies 
aimed at testing tite hypothesis that alterations in $\mathbf{G}$ protein function contribute to the complex neuroadaptive mechanisms involved in the clinical actions of ADs:

1. There is increasing evidence from both animal models of depression and clinical trials that the 5-HT ${ }_{1 A}$ receptor participates in the mechanisms of action of ADs (Murphy et al 1991). However, the effects of chronic administration of conventional ADs on $5-\mathrm{HT}_{1 A}$ function is less clear; the behavioral, functional and biochemical evidence suggests an attenuation of 5-HT $1 A$ function in rodents and humans (Grahame-Smith 1988; Wozniak et al 1988; Lesch 1991; Lesch et al 1991c), whereas electrophysiological evidence suggests an enhancement of 5-HT ${ }_{1 A}$ function in hippocampus in the animal model (Chaput el al 1991), both of which occur in the absence of consistent alterations in 5-HT $1 A$ receptor binding parameters (Hensler et al 1991). Because the 5-HT ${ }_{1 A}$ receptor is directly coupled to $\mathrm{K}^{+}$and $\mathrm{Ca}^{2+}$ channels (likely via $G_{i}$ and $G_{o}$ ), and to inhibition of adenylyl cyclase (via $G_{i}$ ), one mechanism to explain these seemingly disparate findings would be differential effects of $A D s$ on $G_{i}$ and $G_{o}$. We have therefore examined the effects of chronic (3-week) administration of different classes of ADs (selective and nonselective TCAs, MAOI) on G protein steady-state concentrations and function using enzymelinked immunosorbent assay (ELISA), immunoblotting, and toxin-catalyzed ADPribosylation techniques, in various areas of the rat brain.

2. In view of the delayed and persistent therapeutic effects of ADs, we hypothesized that these drugs may also exert effects at the level of neuronal gene expression. Thus, we have used quantitative Northern blot analysis and RNase protection assay techniques to investigate $A D$-induced alterations in $\mathbf{G} \alpha_{o}, \mathbf{G} \alpha_{i 1-3}, G \alpha_{o}, \mathbf{G} \alpha_{q}$, and $\mathrm{G} \alpha_{12}$ mRNA expression in rat brain during long-term administration of the selective 5-HT reuptake inhibitor, fluoxetine, in comparison to TCAs (imipramine, desipramine, clomipramine) and the MAO-A inhibitor clorgyline.

3. In addition, we describe the polymerase chain reaction-(PCR) mediated crossspecies partial cDNA cloning and sequencing of rat and human $G \alpha_{q}$ and rat $G \alpha_{12}$, as well as the regional distribution of their messages in comparison to $\alpha$ subunits of the $G_{o}$ and $G_{i}$ class in rat brain.

4. Finally, to elucidate the role of presynaptic neuronal input on AD-induced alterations in $\beta$-adrenergic receptors and second messenger generation, we have utilized cultured rat $\mathrm{C} 6$ glioma cells. We report the effects of chronic in vitro administration of two structurally dissimilar antidepressants, desipramine and idazoxan (an $\alpha_{2}$ adrenergic antagonist) on dynamic $\beta$-receptor binding parameters, $G \alpha$ protein immunoblotting, toxin-catalyzed ADP-ribosylation, as well as receptor- and postreceptor-stimulated adenylyl cyclase activities.

Though almost exclusively unpublished data are presented in this article, some relevant previously communicated data are also reviewed, in order to demonstrate the complementarity of the results using different methodologies, and to highlight our rationale for examining the effects of $\mathrm{ADs}$ on $\mathrm{G}$ proteins at the level of neuronal gene expression.

\section{Methods}

\section{Animal Studies}

Chronic Antidepressant Treatment. Male Wistar rats (initial weight approximately 250 g) were housed in a temperature-controlled $\left(24 \pm 1^{\circ} \mathrm{C}\right)$ room with a 12-hr light-dark 
cycle (light on at 7:00 AM). All animals had free access to food and water. Imipramine (IMI; $5 \mathrm{mg} / \mathrm{kg} /$ day), clomipramine (CMI; $5 \mathrm{mg} / \mathrm{kg} /$ day), desipramine (DMI; $5 \mathrm{mg} / \mathrm{kg} /$ day), fluoxetine (FLX; $2.5 \mathrm{mg} / \mathrm{kg} /$ day, clorgyline (CLG; $1 \mathrm{mg} / \mathrm{kg} /$ day), or saline was subcutaneously administered continuously by means of osmotic minipumps for 21 days; the pumps were reimplanted at 2 wks. The selection of doses of ADs was based on previous work from our laboratory (Aulakh et al 1988; Wozniak et al 1988) and on the clinical dosage of these ADs. Each osmotic minipump was $2.5 \mathrm{~cm}$ long with a mean pumping rate of $0.49 \mu / \mathrm{h}$ and a mean fill volume of $193 \mu \mathrm{l}$. The volume injected was $0.1 \mathrm{ml} / 100$ $\mathrm{g}$ of body weight.

Membrane Preparation and Immunoblotting. After rapid removal, brains were dissected on an ice-cold glass plate as follows. Frontal cortex: the frontal cortical poles, dorsal to and excluding the olfactory tubercle and anterior to the corpus callosum. Hypothalamus: a wedge with 45-degree angle toward the midline, circumscribed by the circle of Willis with the anterior commissure as a horizontal reference and the line between the osterior hypothalamus and the mammillary bodies as the caudal limit. Hippocampus: the medial pole excluding the entorhinal cortex with the lateral ventricle as rostral limits and the alveus as dorso-lateral limits. Neostriatum: caudate and putamen with the external walls of the lateral ventricles as internal limits and the corpus callosum as external limits. Raphe nuclei: midline sagittal section $2 \mathrm{~mm}$ in width, caudal to the inferior colliculus (including median and dorsal raphe). Locus coeruleus: the dorsal one-third of a coronal section $1 \mathrm{~mm}$ in width, caudal to the inferior colliculus. Cerebellum: left hemisphere.

Tissue samples were homogenized in $50 \mathrm{mM}$ Tris- $\mathrm{HCl}$ (pH 7.4) containing $2 \mathrm{mM}$ dithiothreitol and $1 \mathrm{mM}$ EDTA and centrifuged at $1000 \mathrm{~g}$ for $10 \mathrm{~min}$. The resulting supernatant was then centrifuged at $40,000 \mathrm{~g}$ for $20 \mathrm{~min}$ at $4^{\circ} \mathrm{C}$, and membrane protein extracted for $1 \mathrm{hr}$ at $4^{\circ} \mathrm{C}$ in $20 \mathrm{mM}$ Tris $-\mathrm{HCl}$ (pH 8.0) containing $25 \mathrm{mM} \mathrm{NaCl}, 1 \mathrm{mM}$ EDTA, and $1.0 \%$ sodium cholate. The extract was centrifuged at $20,000 \mathrm{~g}$ for $1 \mathrm{hr}$ at $4^{\circ} \mathrm{C}$ and the supernatant utilized for incubation with antibody. Antibodies were directed against synthetic decapeptides corresponding to the carboxy termini of the respective $\mathrm{G} \alpha_{s}, G \alpha_{i 1 / 2}, G \alpha_{o}$, and $\mathrm{G} \alpha_{q}$ subunit (Figure 1) (Spiegel et al 1990). The specificity of the $\mathrm{G} \alpha_{s}, \mathrm{G} \alpha_{i / 2}$ and $\mathrm{G} \alpha_{0}$ antibodies was assessed in native membrane extracts from cortex and hippocampus by immunoblotting (Western blotting). The homogenates from rat frontal cortex and hippocampus were subjected to SDS-PAGE on $10 \%$ polyacrylamide gels. Proteins resolved by SDS-PAGE were then electrophoretically transferred to nitrocellulose membranes for $2 \mathrm{hr}$. Nonspecific binding on the nitrocellulose was blocked with detergent containing $50 \mathrm{mM}$ Tris- $\mathrm{HCl}(\mathrm{pH} 8.0), 2 \mathrm{mM} \mathrm{CaCl}, 80 \mathrm{mM} \mathrm{NaCl}, 5 \%$ nonfat dry milk, $0.2 \% \mathrm{NP}-40$, and $0.02 \% \mathrm{NaN}_{3}$. Blots were then incubated at room temperature overnight with polyclonal anti-G $\alpha$ antibodies (anti-G $\alpha_{s}$, anti-G $\alpha_{i 1 / 2}$, anti-G $\alpha_{o}$, anti-G $\alpha_{q}$; antibody characteristics are summarized in Figure 1). After three washes, the nitrocellulose membranes were incubated with [ $\left.{ }^{125} \mathrm{I}\right]$ protein $\mathrm{A}$ for $1 \mathrm{hr}$. The blots were then washed, dried, and exposed to x-ray film with intensifying screens at $-70^{\circ} \mathrm{C}$. Quantitation of immunoblots was performed by densitometric scanning of the autoradiograms using a laser scanner and an image analysis system. A standard amount of rat brain (cortex or hippocampus, $30 \mathrm{ng}$ ) was added to one lane of each gel, and the $\mathrm{G} \alpha$ immunoreactivity in each lane was calculated relative to this standard.

Enzyme-Linked Immunosorbent Assay (ELISA). Quantitation of $\mathrm{G \alpha}_{s}, \mathrm{G \alpha} \alpha_{i 1 / 2}$, and $\mathrm{Ga}_{o}$ was performed using competitive ELISAs as previously described (Lesch et al 1991a,b). 


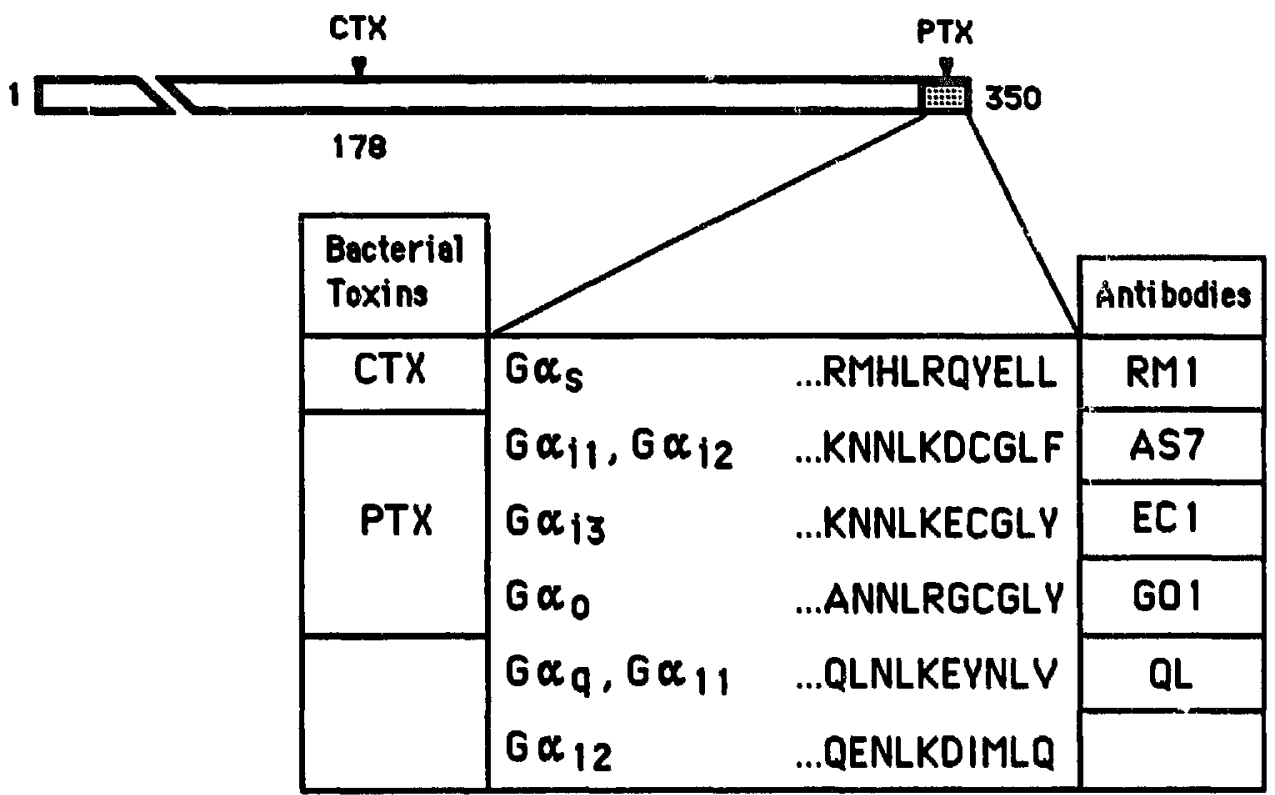

Figure 1. Diagram of the $G \alpha$ subunit characteristics used for detection by cholera toxin- and pertussis toxin-catalyzed ADP-ribosylation and antibodies directed against the $\mathrm{C}$ terminus. CTX, site of ADP-ribosylation by cholera toxin. PTX, site of ADP-ribosylation by pertussis toxin. Hatched bnx, amino acid sequence (single letter code) of the Ga $C$ terminus.

Ninety-six well polystyrene microtiter plates were coated overnight at $4^{\circ} \mathrm{C}$ with $100 \mathrm{ml}$ of synthetic peptide solution per well $(0.01-0.03 \mathrm{mg} / \mathrm{ml}$ in $0.2 \mathrm{M}$ sodium carbonate buffer, $\mathrm{pH}$ 9.6). Antibody binding to coated wells in relation to peptide coating concentration and antibody dilution was optimized by checkerboard titration. In studies to validate the specificity of the antibodies, immunoblot analyses indicated that the $\left(j \alpha_{s}\right.$ antibody was specific for the corresponding $\mathrm{G} \alpha_{s}$ subunit, the $\mathbf{G} \alpha_{1}$ antibody equivalently recognized the 41 and $40 \mathrm{kDa}$ forms ( $\mathrm{G} \alpha_{i 1}$ and $\mathrm{G} \alpha_{i 2}$, respectively), while the $G \alpha_{o}$ antibody exhibited substantial cross-reactivity with $\mathrm{G} \alpha_{13}$ (Figure 1).

For $\mathrm{G} \alpha$ subunit quantitation, membrane extracts $(\sim 10 \mu \mathrm{g}$ membrane protein) or standards were applied to peptide-coated wells in triplicate with a 1:2,000-1:\$,000 dilution of antibodies in an incubation mixture having the final composition $0.2 \%$ sodium cholate, 1.0\% Tween-20, $20 \mathrm{mM}$ Tris- $\mathrm{HCl}$ (pH 8.0), $25 \mathrm{mM} \mathrm{NaCl}$, and $1 \mathrm{mM}$ EDTA and incubated at $4^{\circ} \mathrm{C}$ overnight. Following washing, peroxidase-coupled goat anti-rabbit lgG antibodies $(1: 4,000)$ were added. After $2 \mathrm{hr}$, substrate solution $\left(\mathrm{ABTS} / \mathrm{H}_{2} \mathrm{O}_{2}\right.$ ) was added and color development detected at $415 \mathrm{~nm}$.

Multivariate analysis of variance (the MANOVA statistic reported here is Wilks' Lambda) comparing the treatments, including a contrast of each drug against control, simultaneously across all brain regions was performed for each of the $\mathbf{G} \alpha$ subunits. In addition, for each brain region, treatments were compared using Fisher's P-LSD following a significant one-way ANOVA.

Toxin-Catalyzed ADP-Ribosylation of $G$ Proteins. G protein a subunit ADP-ribosylation sites are indicated in Figure 1. For cholera or pertussis toxin-catalyzed ${ }^{32} \mathrm{P}$-labeling, membranes were prepared as described above and then resuspended in potassium phos- 
phate buffer ( $\mathrm{pH} \mathrm{7.5).} \mathrm{Membranes} \mathrm{were} \mathrm{incubated} \mathrm{at} 37^{\circ} \mathrm{C}$ for $60 \mathrm{~min}$ in a final volume of $200 \mu \mathrm{l}$, containing $100 \mathrm{mM}$ potassium phosphate, $10 \mathrm{mM}$ thymidine, $10 \mathrm{mM}$ arginine, $0.5 \mathrm{mM}$ ATP, $50 \mathrm{mM}$ GTP, $10 \mathrm{mM}\left[\alpha-{ }^{32} \mathrm{P}\right] \mathrm{NAD}(25 \mathrm{Ci} / \mathrm{mmol})$, with and without activated toxin. Prior to incubation, both cholera toxin ( $10 \mu \mathrm{g} / \mathrm{tube})$ and pertussis toxin $(5 \mu \mathrm{g} / \mathrm{tube})$ were activated with $10 \mathrm{mM}$ dithiothreitol for $30 \mathrm{~min}$ at $37^{\circ} \mathrm{C}$. Labeled membranes were washed in ice-cold buffer, solubilized, and subjected to SDS-PAGE on $10 \%$ polyacrylamide gels. After electrophoresis, gels were dried and exposed to $\mathrm{x}$-ray film with an intensifying screen at $-70^{\circ} \mathrm{C}$. Labeled protein bands were identified by comparison with standards of known molecular weights. Quantitation of ${ }^{32} \mathrm{P}$ incorporation was accomplished by densitometric scanning of the autoradiograms.

Northern Blot Analysis. After rapid removal, brain regions [frontal cortex, hypothalamus, hippocampus, neostriatum, midbrain (midline sagittal section $2 \mathrm{~mm}$ in width including the dorsal and median raphe)] and cerebellum (left hemisphere) were dissected on ice and total RNA was extracted using methods previously described (Chomczynski and Sacchi 1987). Briefly, tissue samples were homogenized in $4 \mathbf{M}$ guanidine thiocyanate, $25 \mathrm{mM}$ sodium citrate ( $\mathrm{pH} 7.5$ ), $0.5 \%$ sarcosyl, $0.1 \mathrm{M} \beta$-mercaptoethanol. After acidified phenol-chloroform extraction and isopropanol precipitation, the RNA was washed in 75\% ethanol, quantitated by photometry at $260 \mathrm{~nm}$ and by densitometry of photographic negatives of $1 \%$ agarose gels containing $2 \mu \mathrm{g} / \mathrm{ml}$ ethidium bromide (Hough and Chuang 1990 ), and stored at $-80^{\circ} \mathrm{C}$.

Total RNA (5-10 $\mu \mathrm{g} / \mathrm{lane})$ was fractionated on 1.0\% agarose $/ 2.2 \mathrm{M}$ formaldehyde gels and transferred to nitrocellulose membranes by capillary blotting. antisense [ ${ }^{32}$ P]cRNA was produced by in vitro transcription of linearized subclones derived from rat $\mathbf{G} \alpha$ fulllength cDNA or from PCR-generated cDNA fragments in the pGEM-3/4i vector using SP6 or T7 RNA polymerase. The cRNA probes used in this study were directed to a domain corresponding to nucleotides $\sim 260-480$ of the coding region that exhibits maximal sequence diversity among the $\alpha$ subunit and transcribe from CDNA templates with the following characteristics: $G \alpha_{s}$, Sty I-Pst I fragment (nucleotide 449-800 of the coding

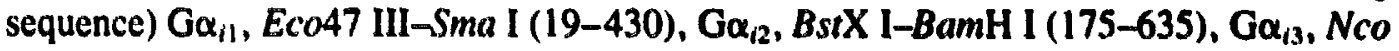

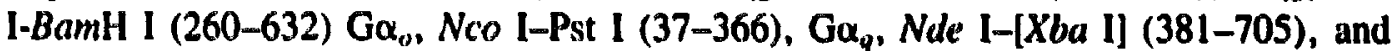
$\mathrm{G} \alpha_{12}$, Xho $1-[X b a \mathrm{I}](327-629)$. Figure 2 depicts the templates constructed for in vitro transcription of antisense [ $\left.{ }^{32} \mathrm{P}\right] \mathrm{CRNA}$ probes.

Hybridization was carried out in $50 \%$ formamide, $5 \times$ SSPE, $5 \times$ Denhardt's solution, $1 \%$ SDS, $10 \%$ dextrane sulfate, $100 \mu \mathrm{g} / \mathrm{ml}$ salmon sperm DNA, at $55^{\circ} \mathrm{C}$ for $18 \mathrm{hr}$. Blots were washed to a final stringency of $0.1 \times$ SSC, $0.1 \%$ SDS at $72^{\circ} \mathrm{C}$. Membranes were exposed to Kodak XAR-5 film with intensifying screens at $-80^{\circ} \mathrm{C}$. Northern blots were subsequently reprobed with a $\sim 250$ bp murine $\beta$-actin antisense [ $\left.{ }^{32} \mathrm{P}\right] \mathrm{CRNA}$ probe. Integrated optical densities of autoradiograms were collected via computerized video densitometry and normalized to $\beta$-actin mRNA or $28 S / 18 S$ rRNA. Sense $\left[{ }^{32} P\right]$ cRNA dilutions were utilized to assure that fim exposures were within the linear range for quantitation.

Analysis of variance with a repeated-measures design of integrated optical densities

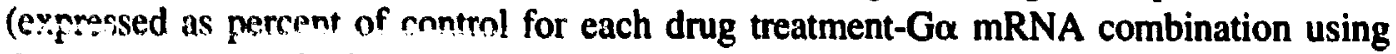
drug treatment as the between factor, brain region and $\mathrm{G} \alpha$ mRNA as the within factors) revealed a significant three-way interaction. Subsequent analyses were made separately for each drug treatment using both one-way analysis of variance and repeated measures procedures to determine drug-dependent differences in $\mathrm{G} \alpha$ mRNA within each brain region. 


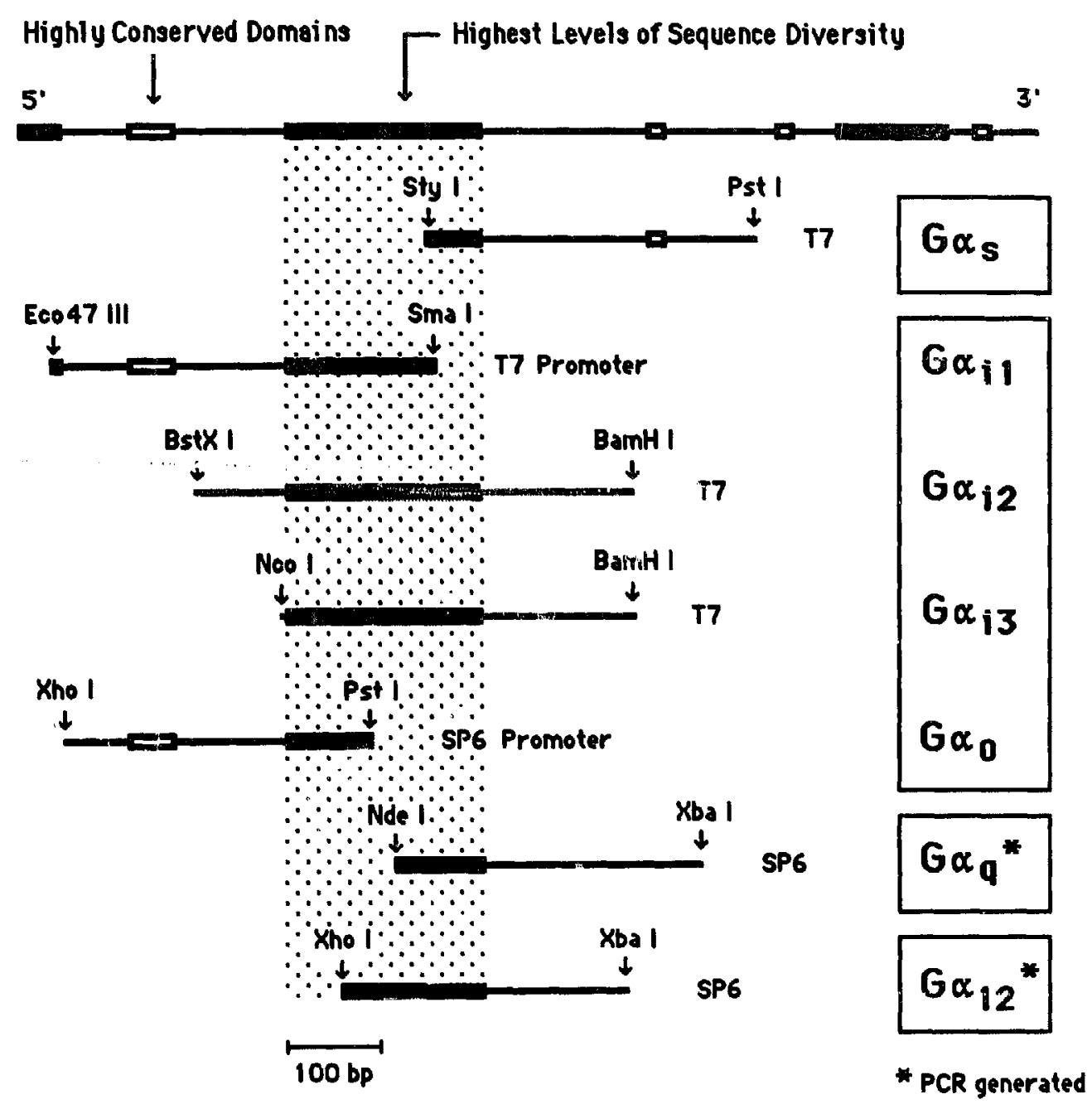

Figure 2. Diagram of the templates used for in vitro transcription of antisense $\left.{ }^{32} \mathrm{P}\right] \mathrm{cRNA}$ probes. Black boxes and hatched area indicates domains with highest levels of sequence diversity. White boxes are highly conserved domains. $\downarrow$, endonuclease restriction sites for subcloning of $G \alpha$ fragments and template linearization. T7 and SP6, promotor for T7 and SP6 RNA polymerase. PCR, polymerase chain reaction.

RNase Protection Assay. To verify significant fluoxetine-induced changes in $\mathrm{G} \alpha$ gene expression mRNA was also quantitated by RNase protection assay techniques. Hybridization of total RNA (2-5 $\mu \mathrm{g})$ and antisense $\mathrm{G} \alpha$ [ ${ }^{32} \mathrm{P}$ ]cRNA was carried out in a final volume of $20 \mu \mathrm{l}$ consisting of $80 \%$ formamide, $40 \mathrm{mM}$ PIPES (pH 6.1), $400 \mathrm{mM} \mathrm{NaOAc}$ (pH 6.4), and $1 \mathrm{mM}$ EDTA, at $45^{\circ} \mathrm{C}$ for $12-16 \mathrm{hr}$. RNA hybrids were digested with 10 mU RNase A/2 U RNase T1 in $200 \mu 10 \mathrm{mM}$ Tris-HCl (pH 7.5) containing $15 \mathrm{mM}$ $\mathrm{NaCl}$ for $30 \mathrm{~min}$ at $37^{\circ} \mathrm{C}$. RNase digestion was terminated with $50 \mu$ l of $4 \mathrm{M}$ guanidine thiocyanate, $25 \mathrm{mM}$ sodium citrate ( $\mathrm{pH} 7.5$ ), $0.5 \%$ sarcosyl, and $0.1 \mathrm{M} \beta$-mercaptoethanol and protected RNA/RNA hybrids precipitated with $250 \mu \mathrm{l}$ isopropanol. After washing with $70 \%$ ethanol the peliet was redesolved and protected fragments were visualized on a $6 \%$ polyacrylamide denaturing gel; radioactivity was measured using a $\beta$-scintillation counter. 
PCR-Mediated Partial cDNA Cloning and Sequencing of Rat and Human Ga and $G \alpha_{12}$. Templates for $G \alpha_{q}$ and $G \alpha_{12}$ cRNA were generated by PCR-mediated cross-species partial cDNA cloning. Poly $(A)^{+}$RNA from rat or human cortex was prepared using guanidine thiocyanate-phenol-chloroform extraction followed by oligo (dT)-cellulose chromatography. sscDNA was synthesized from $10 \mu \mathrm{g}$ poly (A) ${ }^{+}$RNA with $10 \mathrm{U}$ of M-MLV reverse transcriptase and $25 \mu \mathrm{g} / \mathrm{ml}$ random hexamer primers at $37^{\circ} \mathrm{C}$ for 60 min. Oligonucleotide adapter primers used to generate $\mathrm{G} \alpha_{q}$ (sense $\mathrm{Xba}$ I 23mer: 5'AGATCATCGCGAATCGCTTATAC-3'; antisense EcoR I 22-mer: 5'-GTATCAGAACATCTTCACGGCC-3') and $\alpha_{12}$ fragments (sense Xbal 22 mer: $5^{\prime}$-CTTTCCGGTGGTTCCCTTAGCA-3'; antisense EcoR I 22-mer: 5'-TGGTCAAGATCCTGCTGCTGGG-3') flanking the region with maximal sequence diversity were derived from published murine sequences and corresponded to highly conserved domains (Strathmann and Simon 1990; Strathmann and Simon 1991). PCR amplification was carried out in a final volume of $100 \mu$ l consisting of $1-5 \mu$ l sscDNA, $2.5 \mathrm{mM}$ deoxyribonucleotides, $0.25 \mu \mathrm{g}$ sense and antisense adapter primers, $10 \mathrm{mM}$ Tris- $\mathrm{HCl}(\mathrm{pH} 8.3), 50 \mathrm{mM} \mathrm{KCl}, 1.5 \mathrm{mM} \mathrm{MgCl}$, and 2.5 U Taq DNA polymerase. Reaction conditions were determined empirically for each set of primers: annealing was carried out at $61^{\circ} \mathrm{C}\left(\mathrm{Ga}_{q}\right)$ and $65^{\circ} \mathrm{C}\left(\mathrm{G} \alpha_{12}\right)$ for $1 \mathrm{~min}$, extension at $72^{\circ} \mathrm{C}$ for $2 \mathrm{~min}$, and denaturation at $96^{\circ} \mathrm{C}$ for $1 \mathrm{~min}$ for 40 cycles. After analysis by agarose gel electrophoresis and purification, the PCR products were cloned by cleaving with $E c o \mathrm{R} \mathrm{V} X b a$ I and ligating the resultant fragments into the $E c o \mathrm{R} \mathrm{VX}$ ba I site of pGEM-3Z by standard methods. The DHl $\alpha$ Escherichia coli strain was transformed and the presence of the cloned fragments was confirmed by analyzing the products of the plasmid miniprep procedure. To verify that the cloned $G \alpha_{q}$ and $G \alpha_{12}$ fragments were the expected PCR products (that is, displaying a high degree of homology with the murine sequences), sequence analysis of both strands was conducted at least three times using we dideoxynucleotide chain ternination method with modified $\mathrm{T} 7$ polymerase and $\mathrm{pUC} / \mathrm{M} 13$ forward/reverse primers.

\section{Cell Culture Studies}

Cell Culture and Intracellular Cyclic AMP Accumulation. Cultured rat C6 glioma cells (ATCC, Rockville, MD) were grown in Dulbecco's modified Eagle's medium (DMEM), supplemented with $5 \%$ fetal calf serum in a humidified atmosphere of $95 \%$ air, $5 \% \mathrm{CO}_{2}$ at $37^{\circ} \mathrm{C}$. Confluent cultures were routinely subsultured at ratios of $1: 10$ to $1: 20$ and cells were exposed to vehicle, DMI $(1 \mu \mathrm{M})$, or idazoxan (IDZ, $1 \mu \mathrm{M}$ ) for either 1 day (acute) or 5 days (chronic). Intracellular cyclic AMP (cAMP) accumulation was determined by incubating cells in 24-well trays in DMEM buffered with $20 \mathrm{mM}$ HEPES (pH 7.4) containing $30 \mu \mathrm{M}$ rolipram (a nonmethylxanthine phosphodiesterase inhibitor) at $37^{\circ} \mathrm{C}$ for $10 \mathrm{~min}$. The cells were then incubated for an additional $15 \mathrm{~min}$ with varying concentrations of isoproterenol, cholera toxin, or forskolin. Incubations were stopped by the removal of buffer and the addition of $1.0 \mathrm{ml} 0.1 \mathrm{~N} \mathrm{HCl}$. After $30 \mathrm{~min}$, the $\mathrm{HCl}$ was neutralized and cAMP concentrations were determined using a cAMP protein binding kit.

Dynamic $\beta$-Adrenergic Receptor Binding Parameters. C6 cell membranes were prepared for receptor binding assay by polytron homogenization and low- and high-speed centrifugation. $\beta$-Adrenergic receptor binding assays were performed using $\left[{ }^{125} I\right]$ iodocy- 
anopindolol (ICYP) as the radioligand. Binding assays were carried ouc at $37^{\circ} \mathrm{C}$ for 90 $\mathrm{min}$ in a reaction mixture containing $50 \mathrm{mM}$ Tris- $\mathrm{HCl}, 2.5 \mathrm{mM} \mathrm{MgCl}$, and $1 \mathrm{mM}$ EDTA. Binding assays also included $1 \mu \mathrm{M}$ serotonin $\mathrm{HCl}$ to block the possible binding of ICYP to 5-HT, receptors. Saturation experiments were performed to determine the density of $\beta$-receptors and the affinity of ICYP for these receptors. Binding of 5-100 pM ICYP was measured in the absence and presence of $100 \mu \mathrm{M}$ isoproterenol to define specific binding, which represented $90 \%$ of the total binding. The two affinity states of the receptor can be analyzed by steady-state competition experiments with a fixed concentration of labeled antagonist and increasing concentrations of unlabeled agonist. Thus, the ability of 18 concentrations of isoproterenol $\left(10^{-10-10^{-4}}\right)$ to inhibit ICYP $(25 \mathrm{pM})$ was determined. The reaction was terminated by the addition of $5 \mathrm{ml}$ ice-cold $50 \mathrm{mM}$ Tris- $\mathrm{HCl}$ (pH 7.4) containing $10 \mathrm{mM} \mathrm{MgCl}$, and $100 \mathrm{mM} \mathrm{NaCl}$ (wash buffer) to the incubation mixture. This was followed by immediate filtration through Whatman GF/B filters, which were washed twice. Radioactivity on the filters was counted with a gamma counter at an efficiency level of $73 \%$. Each experiment was performed three times and mean values are presented. Radioligand binding parameters were determined using the program LIGAND. The parametrss measured were equilibrium dissociation constant for ICYP $\left(K_{d}\right)$, maximal density of receptors $\left(B_{\max }\right)$, equilibrium dissociation constants for receptor in the low $\left(K_{L}\right)$ and high $\left(K_{H}\right)$ affinity states, and the percent of receptors in the high-affinity conformation $\left(\% \mathrm{R}_{H}\right)$. Analysis of saturation curves for ICYP indicated that one-site binding model provided a better cescription of the model than a two-site model. Competition curves for ( - )isoproterenol and ICYP were resolved into a two-site model with significant improvement $(p<0.01)$ over a one-site model. A three-site binding model did not improve the fit over the two-site model. Individual binding curves from competition experiments were subjected to nonlinear regression analysis in order to estimate highand low-affinity components of agonist binding. Data were analyzed using one-way analysis of variance (ANOVA) and two-tailed Student's t-test for independent samples. In order to confirm the absence of $\alpha_{2}$-adrenergic receptors or "imidazoline receptors" (Michell et al 1989) on C6 glioma cells, saturation binding experiments were performed using $\left[{ }^{3} \mathrm{H}\right]$ idazoxan. $\mathrm{C} 6$ cell membranes were prepared as described above for $\beta$-receptor binding assays. Binding assays were carried out at $25^{\circ} \mathrm{C}$ for $30 \mathrm{~min}$, in a reaction mixture containing $50 \mathrm{mM}$ Tris-HCl, $0.5 \mathrm{mM}$ EDTA (pH 7.4). Binding of increasing concentrations of $\left[{ }^{3} \mathrm{H}\right]$ idazoxan was measured in the absence and presence of $100 \mu \mathrm{M}$ tolazoline to define specific binding. The reaction was terminated by the addition of $5 \mathrm{ml}$ ice-cold wash buffer. This was followed by immediate filtration through Whatman GF/B filters, which were washed twice and radioactivity determined by liquid scintillation spectroscopy.

Toxin-Catalyzed ADP-Ribosylation of G Proteins. Toxin-catalyzed [ $\left.{ }^{32} \mathrm{P}\right] \mathrm{ADP}-\mathrm{ribo}-$ sylation was performed on control and AD-treated C6 glioma membranes largely as described above for rat brain membranes. (G $\alpha$ ADP-ribosylation sites are depicted in Figure 1.) In briel, membranes were incubated with activated toxins and [ $\alpha-32$ P]NAD, washed in ice-cold buffer, solubilized, and subjected to SDS-PAGE. Following electrophoresis, gels were dried and exposed to $x$-ray film with an intensifying screen at $-70^{\circ} \mathrm{C}$. Estimation of the molecular weights of labeled protein bands was made by comparison with standards of known molecular weights. Quantitation of ${ }^{32} \mathrm{P}$ incorporation was accomplished by densitometric scanning of the autoradiograms. 
Immunoblot Analysis of $G$ Proteins. Immunolabeling of $\mathrm{G \alpha}_{s}$, and $\mathrm{G} \alpha_{i 1 / 2}$ in rat $\mathrm{C} 6$ glioma cell membrane was performed largely as described above for rat brain. In brief, C6 1 rembrane samples dissolved in Laemmli buffer were subjected to SDS-PAGE using $10 \%$ polyacrylamide gels. The electrophoretically resolved proteins were transferred to nitrocellulose membranes, which were incubated with specific antibodies to $G \alpha_{s}$ and $\mathrm{G \alpha}_{i 1 / 2}$. Subsequent labeling was accomplished with [ $\left.{ }^{125} \mathrm{I}\right]$ protein $\mathrm{A}$, and the dry blots were then exposed to $x$-ray films with intensifying screens at $-70^{\circ} \mathrm{C}$. Quantitation of the immunoblots was performed by densitometric scanning of the autoradiograms.

\section{Results}

\section{Animal Studies}

Regional Distribution of G $\alpha$ Protein in Rat Brain. Figure 3B summarizes the steadystate concentrations of $G \alpha_{s}, G \alpha_{11 / 2}$, and $G \alpha_{o}$ subunits in various rat brain regions. The mean $\mathrm{G} \alpha_{s}, G \alpha_{i 1 / 2}$, and $\mathrm{G \alpha}_{o}$ subunit concentrations were $8.1 \pm 0.2 \mathrm{pmol} / \mathrm{mg}$ protein (range, $4.0-14.1$ ), $27.0 \pm 0.8 \mathrm{pmol} / \mathrm{mg}$ protein (22.1-36.4), and $56.7 \pm 4.5 \mathrm{pmol} / \mathrm{mg}$ protein (41.9-83.2), respectively. Calculated from these data the average ratio of $\mathrm{G} \alpha_{s}$, $G \alpha_{i 1 / 2}$, and $G \alpha_{o}$ subunits in rat brain was approximately 1:3:7.

Effects of Antidepressant Drugs on G Protein $\alpha$ Subunits (ELISA technique). Changes in concentrations of $\mathrm{G} \alpha_{s}, G \alpha_{i 1 / 2}$, and $\mathrm{G} \alpha_{o}$ subunits during chronic (3-wk) AD treatment are presented in Figure 4 . The significant overall treatment difference across all brain regions observed in the $G \alpha_{s}$ subunit $(F[24,57.05]=1.78, p<0.05)$ resulted because each of the drugs decreased $\mathrm{G} \alpha$, compared with control (mean $\pm \mathrm{SEM}=8.2 \pm 0.6$ $\mathrm{pmol} / \mathrm{mg}$ protein); IMI $(6.4 \pm 0.5, F[6,16]=4.35, p<0.01), \mathrm{CMI}(6.6 \pm 0.8, F=$ $3.42, p<0.05), \mathrm{DMI}(7.5 \pm 1.1, F=5.01, p<0.01), \mathrm{CLG}(6.9 \pm 0.6, F=2.87$, $p<0.05)$. When brain regions were examined individually, $\mathrm{AD}$-induced reduction reached significance in the neostriatum (33\%-42\%) and locus coeruleus $(28 \%-38 \%)$ for all drugs, and in the hippocampus only for IMI (22\%).

Comparison of the cumulative effect of all drugs (IMI, $27.1 \pm 0.9 \mathrm{pmol} / \mathrm{mg}$ protein, $F[6,14]=4.64, p<0.01 ; \mathrm{CMI}, 30.2 \pm 1.0, F=0.92$, ns; DMI, $27.6 \pm 1.3, \mathrm{~F}=$ $2.45, p<0.1, C L G, 26.0 \pm 1.1, F=3.67, p<0.05)$ compared to control $(29.8 \pm$ $1.3)$ across regions revealed a decrease in $\mathrm{G} \alpha_{i 1 / 2}(F[24,50.05]=2.33, p<0.01)$. This desrease was significant for IMI in the hypothalamus (23\%) and hippocampus (32\%), for DMI in the frontal cortex $(27 \%)$, and for CLG in the hypothalamus $(21 \%)$ and neostriatum (19\%).

Figure 3 A: Northern blot analysis of seven $\mathrm{G} \alpha$ isotype mRNAs in rat brain. RNA quantity and quality was assessed by staining of ribosomal RNA (28S/18S) with ethidium bromide and hybridization with antisense $\beta$-actin cRNA. Antisense $\left[{ }^{32} \mathrm{P}\right] \mathrm{CRNA}$ of $\mathrm{G} \alpha$, detected two bands comigrating at 1.9 and $2.0 \mathrm{~kb} . G \alpha_{i 1}$ and $G \alpha_{12}$ cRNA hybridized to single bands at 3.6 and $2.1 \mathrm{~kb}$, respectively. Analysis of mRNA coding for $\alpha$ subunits of $G_{o}$, revealed three bands at $3.4,4.4$, and $6.0 \mathrm{~kb}$, resulting from alternative splicing of a single gene. The $\mathrm{G} \alpha_{q}$ probe also detected multiple messages due to alternate splicing, two large transcripts at $6.5 / 7.5 \mathrm{~kb}$ and a weaker signal at $4.0 \mathrm{~kb}$, while $\mathrm{G \alpha}_{12}$ cRNA hybridized to a single band at $3.6 \mathrm{~kb}$. B: Distribution of $G \alpha_{s}, \mathrm{Got}_{1 / 2}$, and $\mathrm{G} \alpha_{o}$ in rat brain. $F C=$ frontal cortex; $H T=$ hypothalamus; $H C=$ hippocampus; $N S=$ neostriatum; $M B=$ midbrain; $R N=$ raphe nuclei; $L C=$ locus coeruleus; $C B=$ cerebellum. 
A

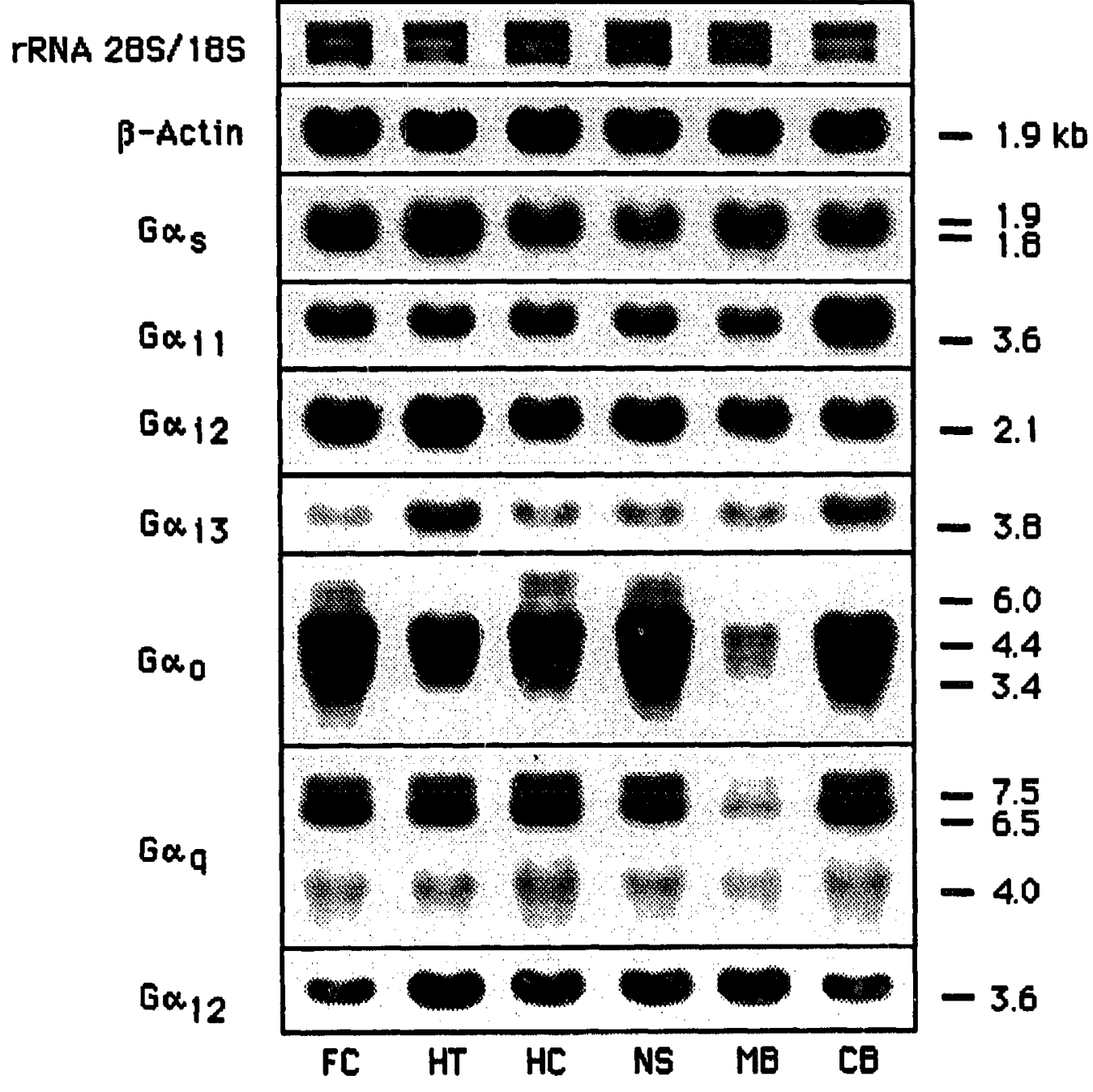

B

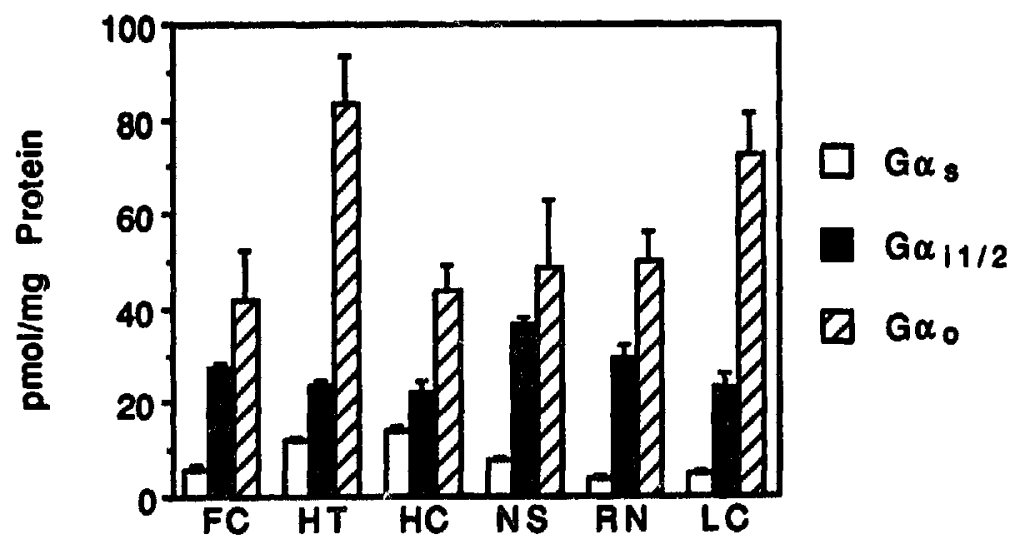



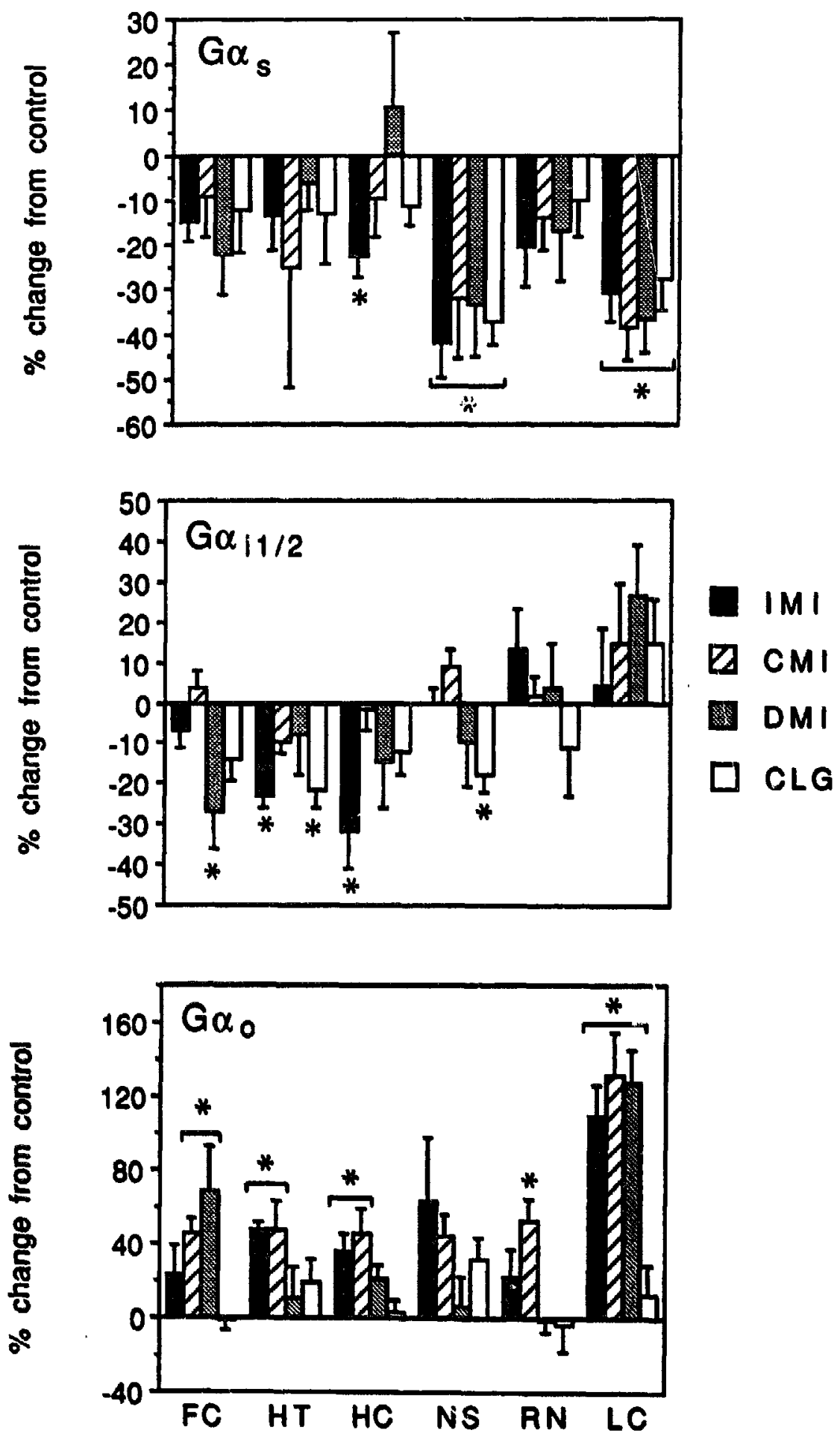

Figure 4. Effects of chronic treatment with imipramine (IMI), clomipramine (CMI), desipramine (DMI), or clorgyline (CLG) on $G \alpha_{s}, G \alpha_{i 1 / 2}$, and $G \alpha_{0}$ in the frontal cortex (FC), hypothalamus (HT), hippocampus (HC), neostriatum (NS), raphe nuclei (RN), and locus coeruleus (LC) of rats using sensitive enzyme-linked immunosorbent competition assays (mean \pm SEM). Asterisk, $p<$ 0.05 , IMI $(n=6), C M I(n=4), D M I(n=4)$, or $C L G(n=6)$ vs controls $(n=6)$, ANOVA followed by Fisher's PLSD (two-tailed). 


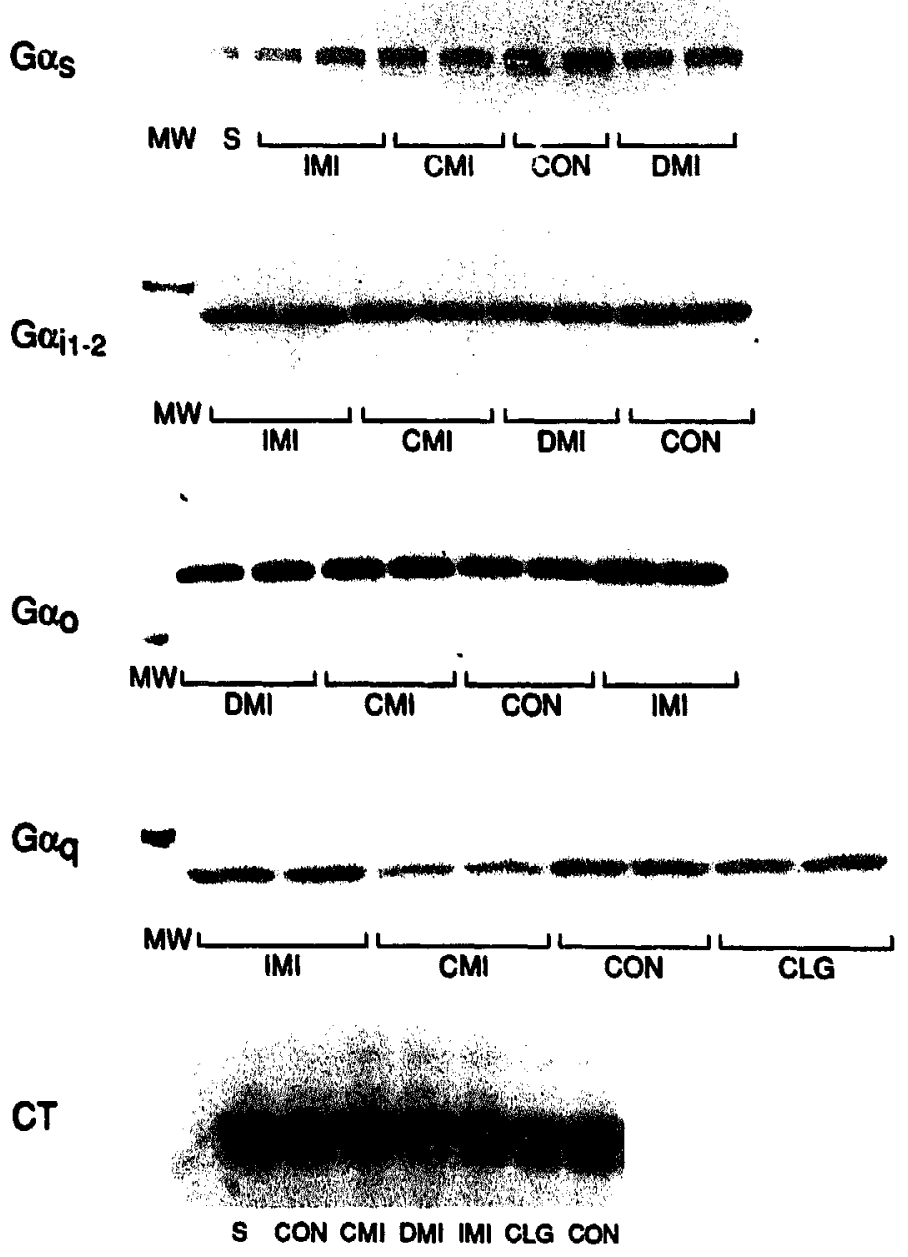

Figure 5. Representative autoradiograms of immunolabeling of $G \alpha_{s}, G_{i 1 / 2}, G \alpha_{o}$ and $G \alpha_{q}$ in rat hippocampus, as well [ ${ }^{32}$ P]ADPribosylated rat hippocampal membranes following chronic treatment with various antidepressants. For immunolabeling, membranes were subjected to SDS-PAGE and electrophoretic transfer as described in the methods section. Immunodetection was performed by polyclonal anti-G $\alpha$ antibodies, and ${ }^{125}$ l-labeled secondary antibody. For [ ${ }^{32}$ P]ADPribosylation studies, membranes were incubated in the presence of preactivated toxins, end subjected to SDS-PAGE. Quantitation of ${ }^{32} \mathrm{P}$ incorporation was accomplished by densitometric scanning of the autoradiograms. $C T=$ cholera toxin; $M W=$ molecular weight standards; $D M I=$ desipramine; $C M I=$ clomipramine; $I M I=$ imipramine; $C O N$ $=$ control; $C L G=$ clorgyline; $S=$ pooled brain tissue.

Though CLG (56.7 $\pm 4.0, F=0.38, \mathrm{~ns})$ had no effect, $\mathrm{G} \alpha_{0}$ was significantly increased during treatment with IMI $(73.6 \pm 4.1 \mathrm{pmol} / \mathrm{mg}$ protein, $F[6,13]=4.85, p<0.01$; CMI, 79.1 $\pm 3.7, F=6.17, p<0.1)$, and DMI $(68.1 \pm 5.0, F=4.14, p<0.05)$ compared with controls $(53.0 \pm 0.4)$. This resulted in a significant overall treatment difference across all brain regions $(F[24,46.56]=2.43, p<0.01)$. When brain regions were examined individually, TCA-induced increases reached significance in the front? 1 cortex for CMI (46\%) and DMI (68\%), in the hypothalamus for IMI (47\%A) and CMI (46\%), in the hippocampus for IMI (36\%) and CMI (45\%), in the raphe nuclei for CMI $(53 \%)$, and in the locus coeruleus for all TCAs $(109 \%-137 \%)$.

Effects of Antidepressants on $G$ Protein $\alpha$ Subunits (Immunolabeling and Toxin-Catalyzed ADP-Ribosylation Techniques). To assess the effects of chronic AD treatment on $\mathbf{G}$ proteins, we also utilized immunolabeling (using specific antisera against $\mathbf{G}$ protein $\alpha$ subunits) and toxin-catalyzed $\left[{ }^{32} \mathrm{P}\right] \mathrm{ADP}$-ribosylation. The $\mathbf{G}$ protein $\alpha$ subunits migrated at apparent molecular masses $\left(\mathrm{G} \alpha_{t} 40-41 \mathrm{kDa} ; \mathrm{G} \alpha_{o} 39 \mathrm{kDa} ; \mathrm{G} \alpha_{s} 52 \mathrm{kDa}\right.$, and $45 \mathrm{kDa}$; $\mathrm{G \alpha}_{q} 42 \mathrm{kDa}$ ) consistent with those reported in the literature (Spiegel et al 1990). Densitometric analysis of the autoradiograms largely confirmed the results obtained by the ELISA methodology described above (representative autoradiograms are shown in Figure 
5). In hippocampus, chronic treatment with IMI significantly reduced the immunolabeling of the $52 \mathrm{kDa}$ form of $\mathrm{Go}_{s}$ (control, $1415 \pm 48.4$; IMI, $1223 \pm 84.1$ OD units; $F[1,19]$ $=7.65, p<0.05)$; CMI produced a near-significant reduction $(p<0.07)$, while CLG and DMI were without effects. All the ADs produced a reduction in the immunolabeling of $\mathrm{G}_{i 1 / 2}$ (control, $1536 \pm 81.7$; IMI, $1223 \pm 84.1, F=7.69, p<0.05$; DMI, 1274 $\pm 48.4, F=4.73, p<0.05)$, although the reduction produced by CLG $(1224 \pm 79.4)$ did not reach significance. All the reuptake inhibitors significantly increased the immunolabeling of $\mathrm{G} \alpha_{o}$ in hippocampus (control, $1475 \pm 80.3$; IMI, $1919 \pm 69.5, F=$ $16.19, p<0.001 ; \mathrm{CMI}, 1758 \pm 118.5, F=5.80, p<0.05 ; \mathrm{DMI}, 1746 \pm 100.5, F$ $=5.31, p<0.05$ ), while the MAOI did not exhibit significant effects $(1580 \pm 50.0)$. All drugs had modest effects on $\mathrm{G} \alpha_{q}$, with only IMI significantly increasing the immunolabeling of this protein $(1380 \pm 51.0$ vs $1626 \pm 59.0, F=6.77, p<0.05)$.

In the frontal cortex, paralleling the ELISA results, all the reuptake inhibitors decreased the immunolabeling of $G \alpha_{o}$; however, not all effects were statistically significant. In contrast to the effects observed in the hippocampus, none of the ADs altered the concentration of $G \alpha_{11 / 2}$, whereas they all reduced the levels of $\mathrm{G} \alpha_{q}$ except for the selective NE reuptake inhibitor, DMI (control, $1802 \pm 101.6$ OD units; IMI, $1397 \pm 113.5$, $F[1,19]=8.85, p<0.01 ; \mathrm{CMI}, 1478 \pm 108.1, F=6.24, p<0.05 ; \mathrm{CLG}, 1501 \pm$ 78.7, $F=5.40, p<0.05$ ).

Partially consistent with the Western blotting data, IMI and CMI modified toxincatalyzed [ $\left.{ }^{32} \mathrm{P}\right]$ ADP-ribosylation in hippocampus. IMI produced small $(\sim 10 \%)$ but significant increases in both choiera toxin- and pertussis toxin-catalyzed [ $\left.{ }^{32} \mathrm{P}\right] A D P-r i b o s y-$ lation. In contrast, CMI produced similar decreases in both, whereas DMI and CLG were without effect. Representative blots of cholera toxin-catalyzed [ ${ }^{32}$ P]ADP-ribosylation of hippocampal membranes are shown in Figure 4.

Regional Expression of $G \alpha m R N A$ in Rat Brain. To elucidate the pattern of $G \alpha$ gene expression in variou, at brain regions, we analyzed messages of multiple $G \alpha$ isotypes by Northern blot analysis. Antisense [ $\left.{ }^{32} \mathrm{P}\right] \mathrm{CRNA}$ of $\mathrm{G} \alpha_{s}$ detected two brands comigrating at 1.9 and $2.0 \mathrm{~kb} . \mathrm{G} \alpha_{i 1}$ and $\mathrm{G} \alpha_{i 2}$ cRNA hybridized to single bands at 3.6 and $2.1 \mathrm{~kb}$, respectively. Analysis of mRNA coding for $\alpha$ subunits of $G_{o}$, revealed three bands at $3.4,4.4$, and $6.0 \mathrm{~kb}$, respectively, resulting from alternative splicing of a single gene. Although the $\alpha$ subunits of the $G_{i}$ class show a high degree of homology, no detectable cross-hybridization among $\mathrm{G} \alpha_{i 1}, G \alpha_{i 2}, G \alpha_{i 3}$, and $\mathrm{G} \alpha_{o}$ was found under high stringency conditions of hybridization. The $G \alpha_{q}$ probe also detected multiple messages due to alternate splicing, two large transcripts at $6.5 / 7.5 \mathrm{~kb}$ and a weaker signal at $4.0 \mathrm{~kb}$, while $\mathrm{G} \alpha_{12}$ cRNA hybridized to a single band at $4.0 \mathrm{~kb}$. Autoradiograms of Northern blots from rat brain revealing a distinct profile for each $\mathrm{G} \alpha$ subunit are shown in Figure 3A. Relatively large amounts of $\mathrm{G} \alpha_{s}$ mRNA were observed in hypothalamus (HT), followed by frontal cortex (FC), cerebellum (CB), midbrain (MB), and hippocampus (HC), with the lowest level in neostriatum (NS). As compared to the other regions the content of $G \alpha_{i 1}$ mRNA was extremely high in cerebellum suggesting the following rank order $(\mathrm{CB}>\mathrm{FC}>\mathrm{HT}>\mathrm{HC}>\mathrm{NS}>\mathrm{MB})$, while $\mathrm{G} \alpha_{i 2}$ and, with considerably lower abundance, $G \alpha_{i 3}$ appeared to be evenly distributed with peak concentrations in hypothalamus. $\mathrm{G} \alpha_{o}(\mathrm{FC}=\mathrm{NS}=\mathrm{CB}>\mathrm{HC}>\mathrm{HT}>\mathrm{MB})$ and $\mathrm{G} \alpha_{q} \operatorname{mRNA}(\mathrm{CB}>\mathrm{HC}>$ $\mathrm{HT}>\mathrm{FC}>\mathrm{NS} \gg \mathrm{MB}$ ) were most abundant in all brain regions except midbrain. The splicing variants of $\mathrm{G} \alpha_{o}$ and $\mathrm{G} \alpha_{q}$ also appeared to be differentially expressed among brain regions. $\mathrm{G \alpha}_{12}$ message was also widely expressed $(\mathrm{HT}>\mathrm{HB}>\mathrm{HC}=\mathrm{NS}>\mathrm{FC}=$ CB). 
G $\alpha$ mRNA Expression and Antidepressant Drugs. Each of the drug treatments resulted in a distinct overall pattern across brain regions (Figure 6A and $\mathrm{B}$ ). IMI induced a significant increase in concentrations of $G \alpha_{s}$ mRNA in the neostriatum $(F[1,10]=5.4$, $p<0.05)$ and midbrain $(F=19.0, p<0.01)$, of both $\mathrm{G} \alpha_{i 1}(F=4.9, p<0.05)$ and $\mathrm{G} \alpha_{o}$ mRNA $(F=8.9, p<0.05)$ in the midbrain, of $\mathrm{G} \alpha_{q}$ mRNA in the hypothalamus $(F=12.7, p<0.01)$, and of $\mathrm{G \alpha}_{12} \mathrm{mRNA}$ in the frontal cortex $(F=5.1, p<0.05)$ and neostriatum $(F=43.3, p<0.001)$. DMI resulted in a significant increase in both $\mathrm{G \alpha}_{s}(F[1,10]=7.5, p<0.05)$ and $\mathrm{G} \alpha_{12}$ mRNA $(F=10.7, p<0.01)$ in the neostriatum, in $\mathrm{G} \alpha_{i 1}(F=11.5, p<0.01)$ and $\mathrm{G} \alpha_{o} \mathrm{mRNA}(F=4.6, p<0.05)$ in the midbrain, and in $\mathrm{G} \alpha_{q}(F=5.4 p<0.05)$ and $\mathrm{G} \alpha_{12}$ mRNA $(F=42.6, p<0.001)$ in the frontal cortex. It decreased $\mathrm{G} \alpha_{i 2}$ mRNA in the hypothalamus $(F=4.4, p<0.05)$. CMI increased $\mathrm{G} \alpha_{s}(F[1,10]=15.2, p<0.01)$ and $\mathrm{G} \alpha_{q} \operatorname{mRNA}(F=6.6, p<0.05)$ in the neostriatum, but decreased $\mathrm{G} \alpha_{12}$ in the hippocampus $(F=25.3, p<0.001)$. CLG caused a significant increase in concentrations of $\mathrm{G} \alpha_{s} \mathrm{mRNA}$ in the hippocampus $(F=6.1, p<0.05)$, of $\mathrm{G} \alpha_{12}$ mRNA in the neostriatum $(F=5.2, p<0.05)$, and of $G \alpha_{12}$ mRNA in both the frontal cortex $(F=10.0, p<0.01)$ and midbrain $(F=10.9, p<0.01)$. It resulted in significant decreases in $\mathrm{G} \alpha_{s}$ mRNA in the frontal cortex $(F=13.1, p<0.01)$, in $\mathrm{G} \alpha_{o}$ in both the frontal cortex $(F=6.6, p<0.03)$ and hypothalamus $(F=8.7, p<0.05)$, and in $\mathrm{G} \alpha_{q}$ in the hippocampus $(F=6.3, p<0.05)$. Representative Northem blots are shown in Figure $6 A$ and results are summarized in Figure $6 B$.

The selective 5-HT reuptake inhibitor FLX evoked a significant increase in $\mathbf{G} \alpha_{q}$ in the neostriatum $(F=5.3, p<0.05)$ and in $\mathrm{G} \alpha_{12}$ in the frontal cortex $(F=9.9, p<$ 0.01 ), but a decrease in $\mathrm{G} \alpha_{s}$ in the midbrain $(F=18.4, p<0.01)$. Representative autoradiograms of $\mathrm{G} \alpha_{s}, \mathrm{G} \alpha_{q}$, and $\mathrm{G} \alpha_{12}$ Northern hybridization analyses and RNase protection assays are shown in Figure 7.

Human and Rat $G \alpha_{q}$ and $G \alpha_{12}$ Partial $c D N A$ Cloning and Sequence. To obtain rat cRNA probes for the two novel $G \alpha_{q}$ and $G \alpha_{12}$, we used PCR-based cross-species cloning to generate rat cDNA fragments. The PCR primers described in this report were derived from published murine sequences and designed to anneal to highly conserved domains but flanking a coding region with maximal sequence diversity. The predicted PCR fragment of $\mathrm{G} \alpha_{q}$ spanned nucleotides 237-705 of the mouse cDNA clone and was $468 \mathrm{bp}$ in length. Amplification of rat brain cDNA also yielded a $G \alpha_{12}$ fragment of the predicted size (nucleotides $164-629,465 \mathrm{bp}$ ). The $\mathrm{G} \alpha_{q}$ and $\mathrm{G} \alpha_{12}$ fragments generated by PCR and the cDNA template constructs for the transcription of antisense $\left[{ }^{32} \mathrm{P}\right] \mathrm{cRNA}$ probes are depicted in Figure 2 and Figure 8. Both strands of the $G \alpha_{q}$ and $G \alpha_{12} \mathrm{CDNA}$ were sequenced at least three times to ensure accuracy. The PCR products share $96 \%$ and $97 \%$ sequence homology with the murine $G \alpha_{q}$ and $G \alpha_{12}$, respectively. Although most differences between rat and murine $G \alpha_{q}$ and $G \alpha_{12}$ genes involves conservative codon changes, in rat $\mathrm{G} \alpha_{12}$, a substitution of a cytosine with a guanine at the position 490 and a thymine with a cytosine at position 577 of the murine coding sequence changes proline to alanine and phenylalanine to leucine, respectively (Figure 8A). Interestingly, a substitution of a adenosine with a guanine at the position 300 deletes a Xho I endonuclease restriction site in the rat gene which is reintroduced 24 nucleotides upstream by a conservative substitution of a thymine with a cytosine. At the amino acid level rat and murine $\mathrm{G} \alpha_{q}$ and $\mathrm{G} \alpha_{12}$, share $100 \%$ and $99 \%$ sequence homology, respectively.

Using a similar approach we succeeded in cloning and sequencing a partial cDNA of human $\mathrm{G} \alpha_{q}$. The deduced amino acid sequence and comparative alignment of human, rat, mouse, and drosophila forms of $\mathrm{G} \alpha_{q}$ are presented in Figure 8B. The PCR product 
$G \alpha_{12} F C \quad G \alpha_{S} M B \quad G \alpha_{i 1} M B \quad G \alpha_{0} \quad M B$

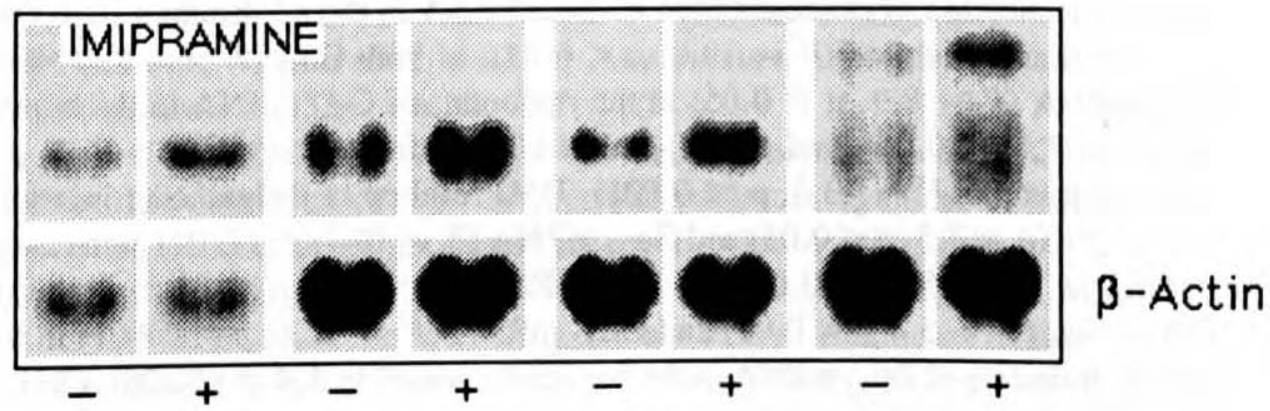

$G \alpha_{q} F C \quad G \alpha_{S}$ NS $G \alpha_{12} N S \quad G \alpha_{i 1} M B \quad G \alpha_{0} M B$
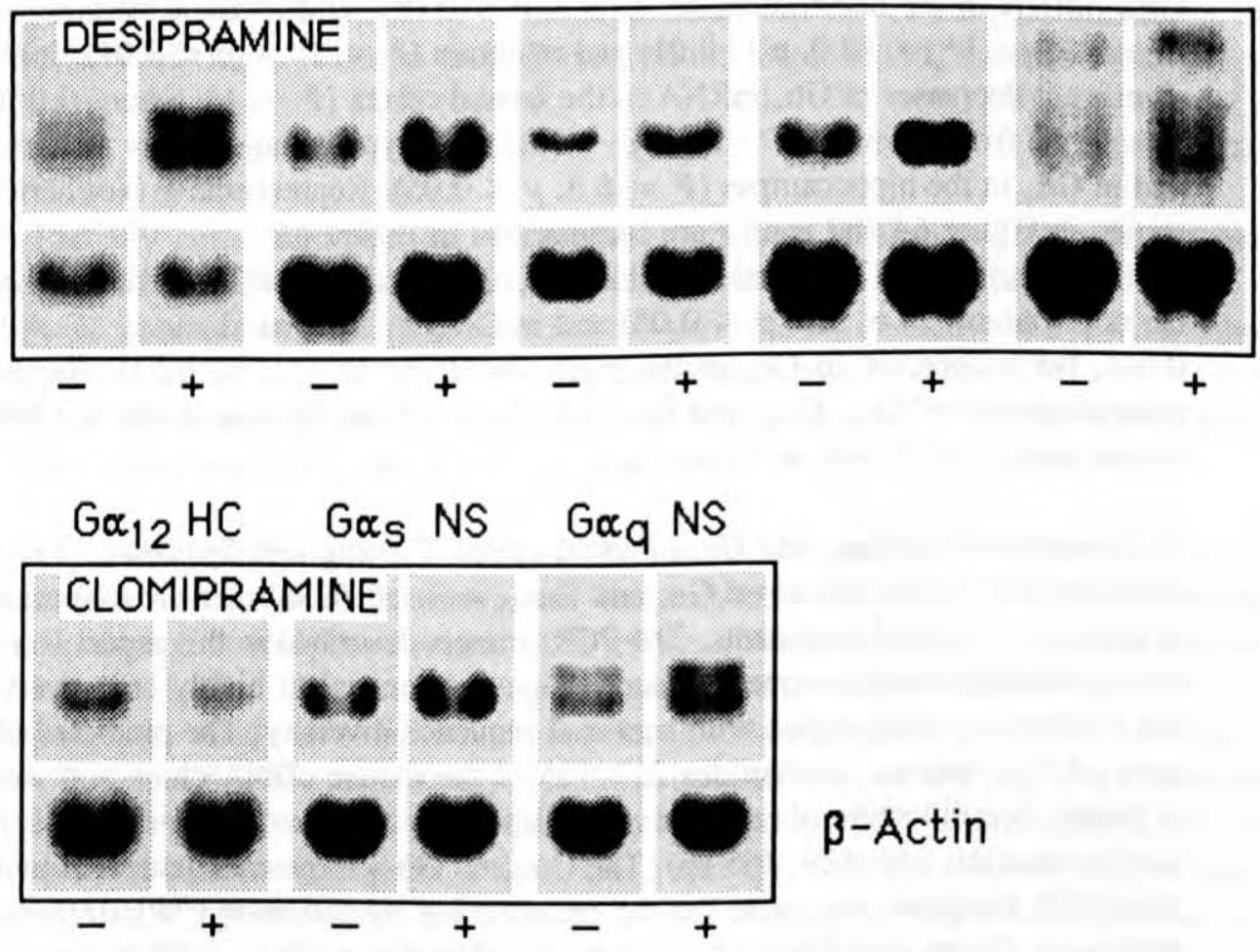

$\mathrm{G}_{\mathrm{S}} \mathrm{FC} \quad \mathrm{G} \alpha_{0} \mathrm{FC} \quad \mathrm{G} \alpha_{12} \mathrm{FC} \quad \mathrm{G} \alpha_{\mathrm{q}} \mathrm{HC} \quad \mathrm{G} \alpha_{i_{2}} \mathrm{NS}$

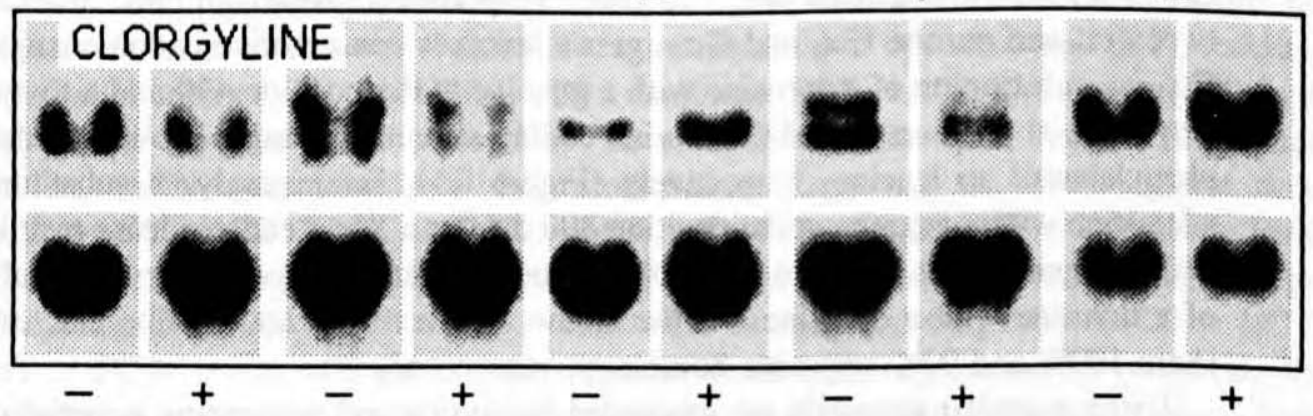

Figure 6A. Representative autoradiograms of Northem blots of $\mathrm{G} \alpha$ mRNAs in various brain areas of the rat following chronic antidepressant treatment with imipramine, desipramine, clomipramine, and clorgyline. Northem blots were subsequently reprobed with a $\sim 250$ bp murine $\beta$-actin antisense $\left.{ }^{32} \mathrm{P}\right] \mathrm{cRNA}$ probe. Integrated optical densities of autoradiograms were collected via computerized
video densitometry and normalized to $\beta$-actin mRNA. 

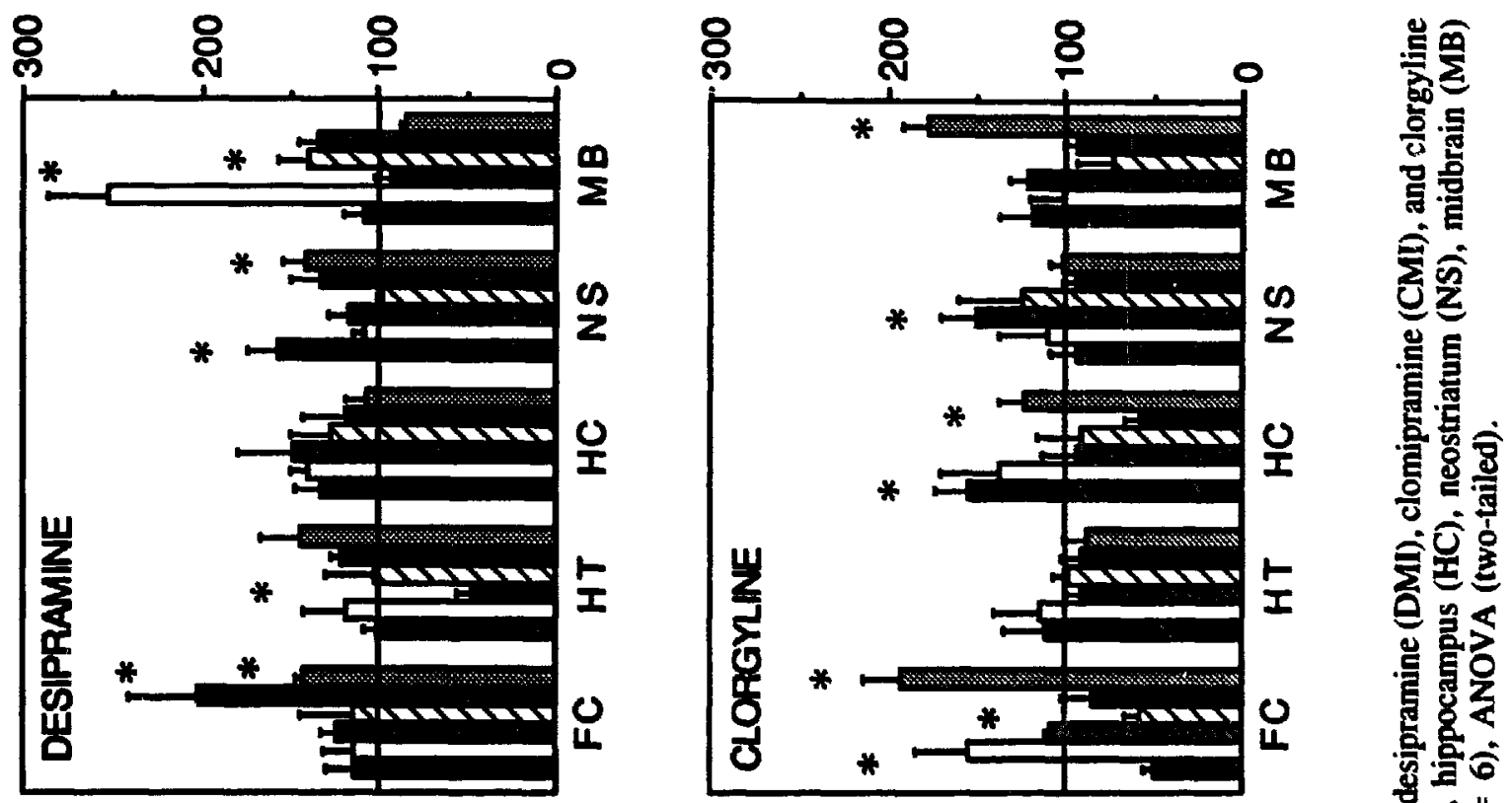
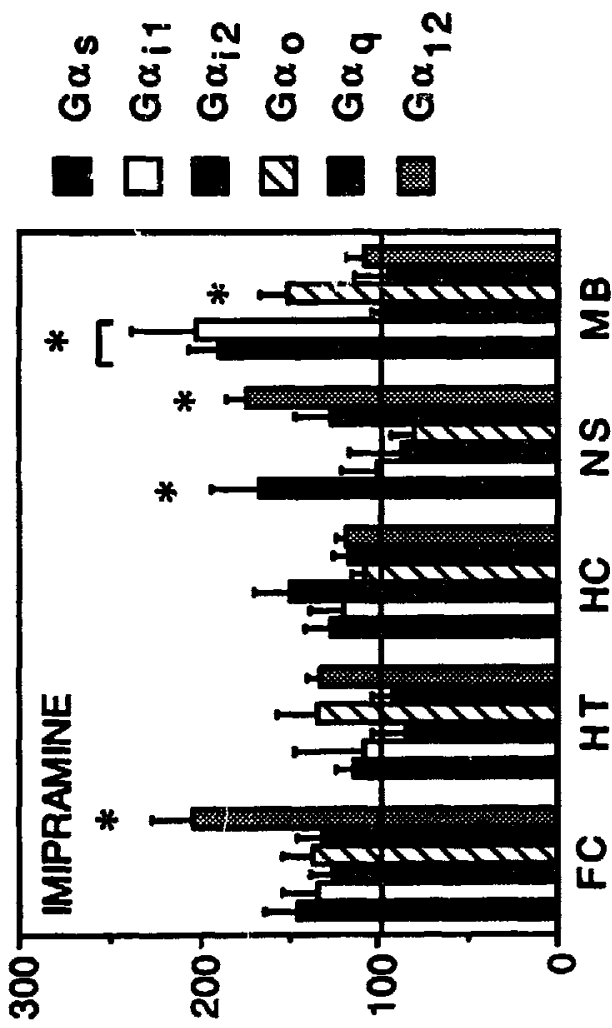

7OHINOS $10 \%$

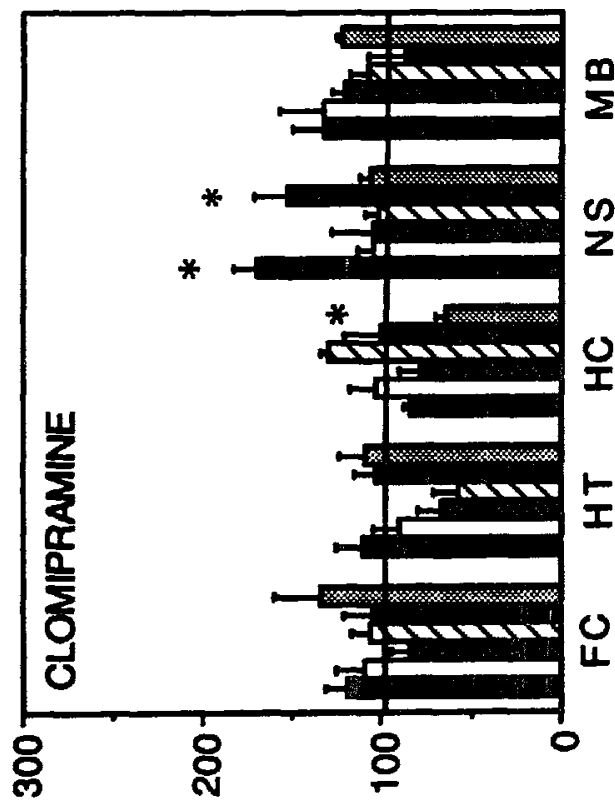

$7041 N O 0$ to $\%$

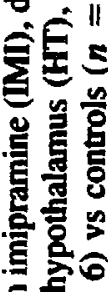

ड़

证政

呵

웅

츨

政

这

흔

응

है

实

远

ธैं⿰

<

政 2

틀

兵

我安

过

焉记 

$G \alpha_{12}$
$G \alpha_{q}$
Gas

\begin{tabular}{|c|c|c|c|c|}
\hline & $\begin{array}{l}\text { Frontel } \\
\text { Cortex }\end{array}$ & Neostriatum & Midbrain & \\
\hline \multicolumn{5}{|l|}{ rRNA 28S/18S } \\
\hline $\begin{array}{l}\text { RNese } \\
\text { Protection } \\
\text { Assey }\end{array}$ & & & 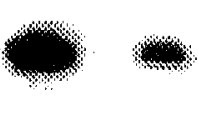 & \\
\hline Northern Blot & & & (x) & $-1.8 k b$ \\
\hline & . & & + & Fluoxetine \\
\hline
\end{tabular}

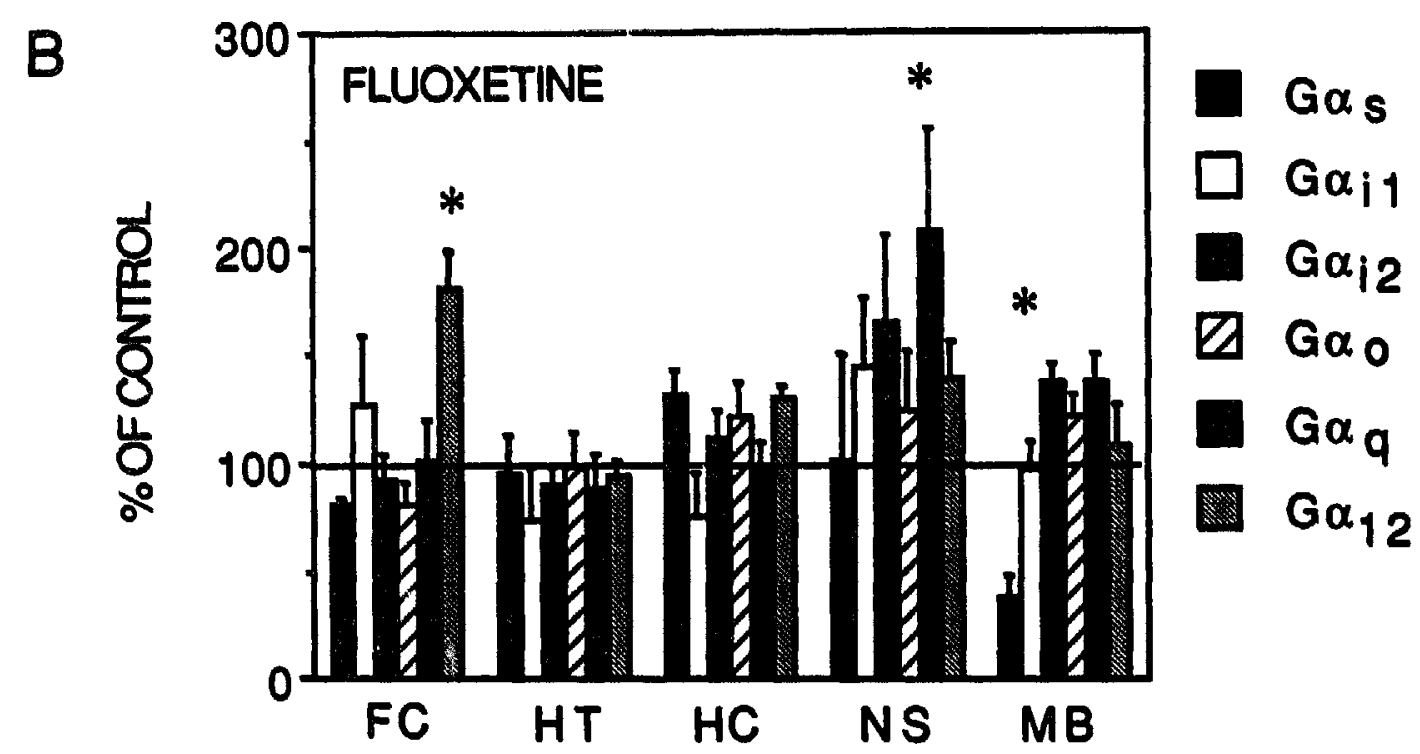

Figure 7. A: Representative autoradiograms of RNase protection assay and Northern hybridization analysis of fluoxetine (FLX)-induced changes in $\mathrm{Ga}_{s}, \mathrm{Ga}_{\varphi}$, and $\mathrm{G} \alpha_{12}$ mRNA expression. RNA quantity and quality was assessed by agarose electrophoresis and visualization of ribosomal RNA (28S/18S) by ultraviolet illumination in the presence of ethidium bromide. B: Summary of the effects of long-term treatment with FLX on $\mathrm{G} \alpha$ mRNAs (mean \pm SEM). Asterisk, $p<0.05 ; F L X(n=6)$ vs controls $(n=6)$; ANOVA (twotailed). 


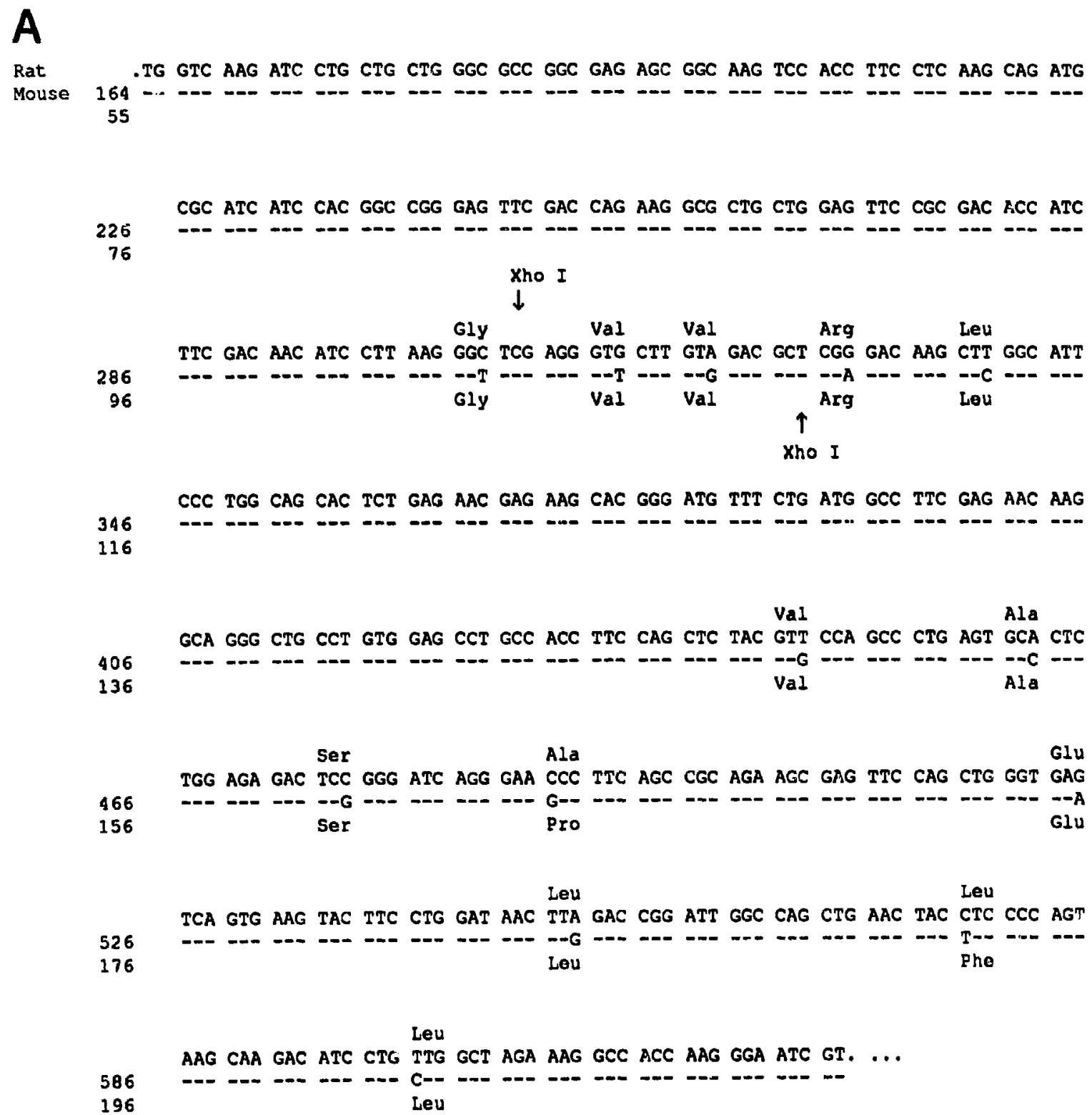

Figure 8A. Nucleotide sequence of rat $\mathrm{Ga}_{12}$ partial cDNA. Underneath the rat sequence, the corresponding murine sequence is represented with substitutions aligned at the appropriate position. Amino acid residues for those codons where there were nucleotide differences are indicated above the cDNA sequence for the rat and below for the mouse. -, nucleotides conserved among rat and mouse; Xho I, internal endonuclease restriction site for template linearization.

shared $95 \%$ and $95 \%$ sequence homology with the murine and rat $\mathrm{G} \alpha_{q}$, respectively, whereas the amino acid sequence was $100 \%$ homologous.

\section{Cell Culture Studies}

Exposure of $\mathrm{C} 6$ glioma cells to either DMl $(1 \mu \mathrm{M})$ or IDZ $(1 \mu \mathrm{M})$ for 5 days was not toxic to the cells, as assessed by microscopic examination of cell morphology, protein 
B

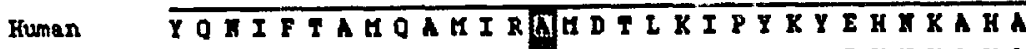

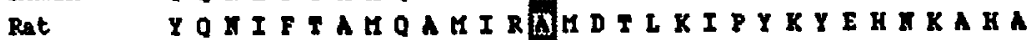
House YOXIFTAKOAUIRAMDTLKIPIKYEHAKAKA Drosophil* Flo I IFG

QLTRETDTERTSAFERBYTDATKSLFTDPGI

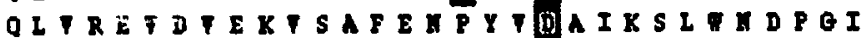
QLTRETDTEXTSAFEXPYTDAIKSI TIDOI DL

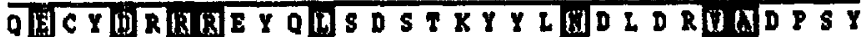

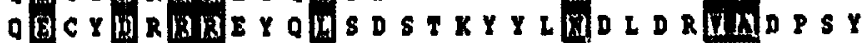
OECYDRRREYQLSDSTXYYLTDEDRTADPSY

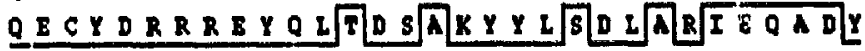

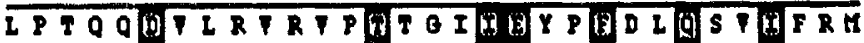

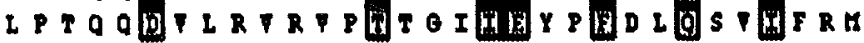
LPTQQDPLRIRTPTIOIIEY PEDLOSTIERI

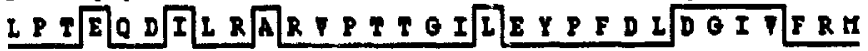

Figure 8B. Deduced amino acid sequence (single letter code) and comparative alignment of human, rat, mouse, and drosophila forms of $\mathrm{G \alpha}_{q}$. Amino acid identities are boxed. Hatched areas indicate conservative codon changes in the rat and human $\mathrm{G}_{q}$ as compared to the murine form.

measurements, trypan blue exclusion, or cell density using a coulter counter. Treatment of the cells with DMI or IDZ for 5 days (but not 1 day) resulted in a significant decrease in the maximum number of $\beta$-adrenergic receptors $\left(B_{\max }\right)$ (Table 1 ). The $>20 \%$ reduction in $B_{\max }$ was, for both drugs, accounted for by a significant and marked decrease in the high affinity form of the receptor, and a smaller, nonsignificant decrease in the low affinity form of the receptor (Table 1). Scatchard analysis of radioligand binding data showed that neither DMI nor IDZ altered the affinity $\left(\boldsymbol{K}_{d}\right)$ of ICYP for $\beta$-adrenoceptors. Similarly, no significant changes were observed in agonist affinity to the low affinity conformation of the receptor $\left(K_{L}\right)$. Both drugs, however, produced significant reductions (control, $5.98 \pm 2.4 \mathrm{nM} ; \mathrm{DMI}, 3.02 \pm 0.7 \mathrm{nM} ; \mathrm{IDZ}, 2.83 \pm 0.06 \mathrm{nM})$ in the dissociation constant for the agonist in the high affinity conformation $\left(K_{H}\right)$ (Table 1), accompanied by significant increases in the $K_{L} / K_{H}$ ratio for the $\beta$-adrenergic receptor. $C 6$ glioma cells showed no specific binding for [ $\left.{ }^{3} \mathrm{H}\right]$ idazoxan (data not shown).

Both the DMI- and IDZ-treated cells accumulated significantly less cAMP than their control counterparts when stimulated with $1 \mu \mathrm{M}$ isoproterenol (Figure 9; ANOVA: $p<$ 0.05). To investigate possible postreceptor components of signal transduction, we examined the CAMP accumulation in response to cholera toxin (which stimulates adenylyl cyclase through $\mathrm{ADP}$-ribosylation of $\mathrm{G \alpha}_{s}$ ) and forskolin (which acts directly on adenylyl cyclase as well as the $G_{s}$ /adenylyl cyclase complex). Neither DMI nor IDZ had any significant effects on cholera toxin or forskolin-stimulated cAMP accumulation (Figure 9). To examine if any lipophilic compound would have the same effects as DMI or IDZ, 


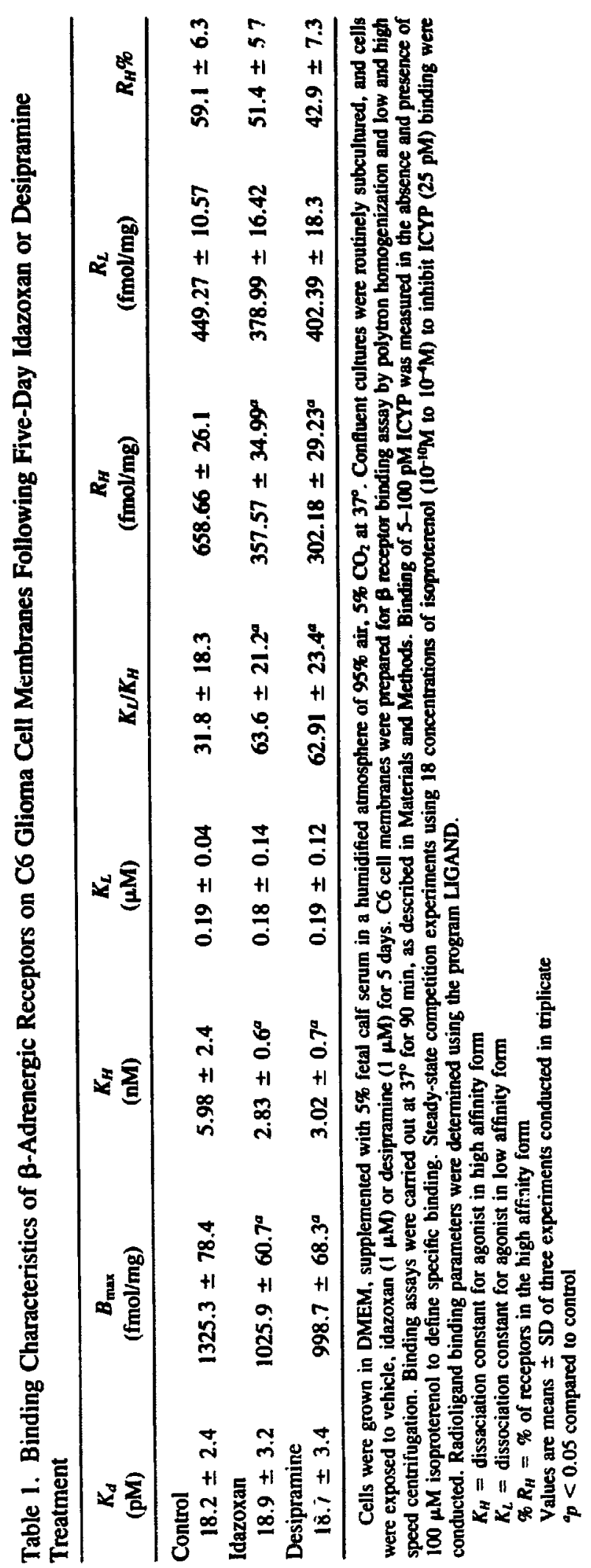




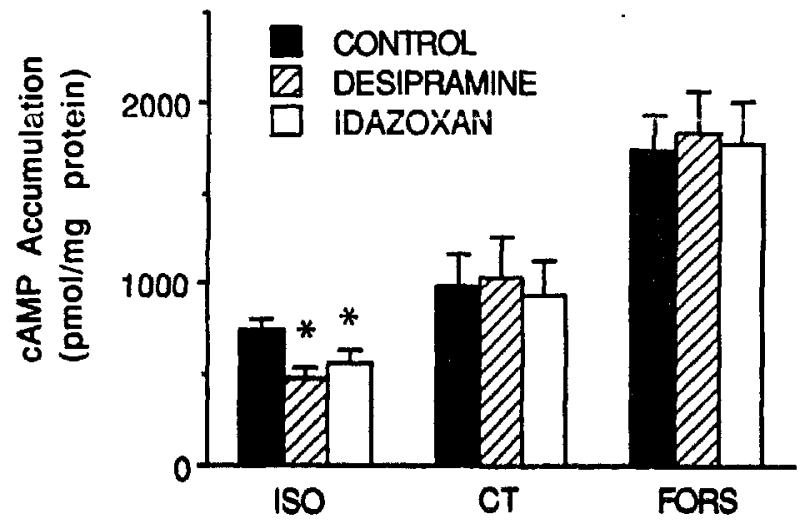

Figure 9. Efiects of five-day desipramine or idazoxan on receptor- and postreceptor-stimulated cyclic AMP (cAMP) accumulation in C6 glioma cells. cAMP accumulation was determined by incubating intact cells in 24 well trays in DMEM/HEPES containing $30 \mu \mathrm{M}$ rolipram at $37^{\circ} \mathrm{C}$ for 10 $\mathrm{min}$. Cells were then incubated for 15 min with either isoproterenol $(1 \mu \mathrm{M})$, cholera toxin $(10 \mathrm{nM})$, or forskolin $(100 \mu \mathrm{M})$. cAMP accumulation was determined by a cAMP protein binding kit. Values are mean \pm SEM of three experiments performed in triplicate. ISO = isoproterenol; $C T=$ cholera toxin; FORS $=$ forskolin; asterisk, $p<0.05$.

C6 cells were also incubated with $1 \mathrm{mM}$ sulpiride (a lipophilic neuroleptic) for 5 days. Sulpiride did not have any significant effects on $\beta$-receptor density or CAMP accumulation (data not shown).

To study the nature of the altered response of adenylyl cyclase, we examined the relative contents of $G \alpha_{s}$ and $G \alpha_{i 2}$ by immunoblotting and toxin-catalyzed ADP-ribosylation (Figure 10). Neither drug affected the immunolabeling of $G \alpha_{S}$ or $G \alpha_{i 2}$, but both drugs produced a small but significant decrease in the cholera toxin-catalyzed [ $\left.{ }^{32} \mathrm{P}\right] \mathrm{ADP}$ ribosylation of the $52 \mathrm{kDa}$ (but not the $45 \mathrm{kDa}$ ) form of $\mathrm{G \alpha}_{s}$ (control, $1892 \pm 198 \mathrm{OD}$ units DMI, $1542 \pm 203 ; \mathrm{IDZ}, 1622 \pm 247 ; p<0.05$ ). Pertussis toxin-catalyzed the [ ${ }^{32}$ P]ADP-ribosylation of a single $40 \mathrm{kDa}$ band in membranes from C6 glioma cells, which was not significantly altered by either treatment (Figure 10).

\section{Discussion}

One of the most exciting recent advances in neuroscience has been the elucidation of the molecular mechanisms underlying neuronal communication, particularly with respect to defining the central role of $G$ proteins in the transduction of a vast array of extracellular, receptor-detected signals across cell membranes to intracellular effectors. Indeed, it has been estimated that about $80 \%$ of all known hormones, neurotransmitters and neuromodulators (numbering around 100) elicit cellular responses through $G$ proteins. Specific characteristics of each isotype of the $\mathbf{G}$ protein classes allows them to associate with a limited number of receptors, and transduce the information to specific effector systems and/or ion channels.

Despite the more modest progress in the elucidation of receptor and effector linkage, cloning and sequencing techniques have facilitated the identification of multiple classes of $G$ protein $\alpha$ subunits designated $G_{s}, G_{i}, G_{q}$, and $G_{12}$. Each class consists of several isotypes which are highly conserved between species but exhibit differential distribution in the CNS. There is now compelling evidence that the $\beta$-adrenoceptor- $G_{s}$-complex stimulates adenylyl cyclase (Birnbaumer 1990), $G_{i 2}$ mediates the inhibition of adenylyl cyclase by $\alpha_{2}$-adrenergic receptors (Kurose et al 1991), both the $G_{s}$ and $G_{i}$ class participate in the regulation of $\mathrm{Ca}^{2+} / \mathrm{K}^{+}$channels, while the coupling of the muscarinic ${ }_{1-s}, 5-\mathrm{HT}_{1 A-E}$, $5-\mathrm{HT}_{2}$, and dopamine ${ }_{1-5}$ receptors to distinct $\mathrm{G}$ protein isotypes has not yet been fully clarified (Liu and Albert 1991; Matesic et al 1991). However, the linkage of $G_{o}$ and $G_{z}$, isotypes of the $G_{i}$ class, to definite receptor subtypes and effector systems is currently 
$\mathrm{G} \boldsymbol{\alpha}_{\mathrm{s}}$

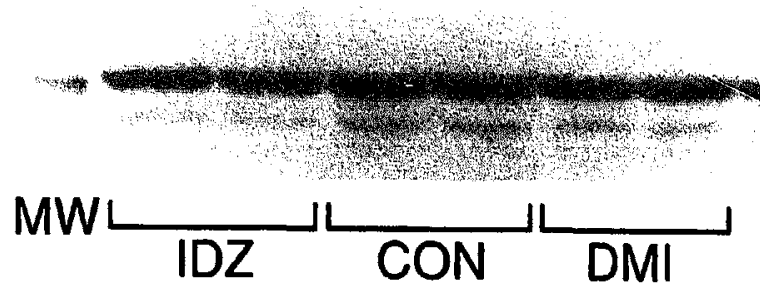

$\mathbf{G} \boldsymbol{\alpha}_{i_{1-2}}$
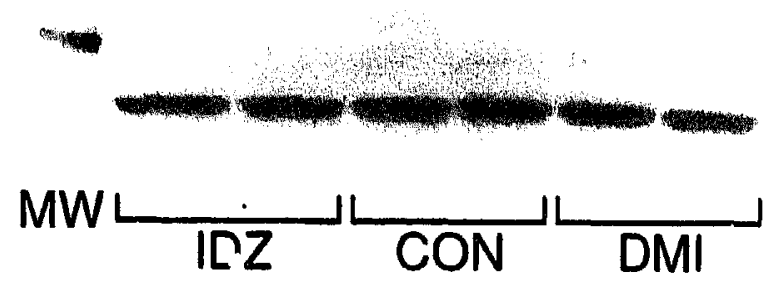

CT

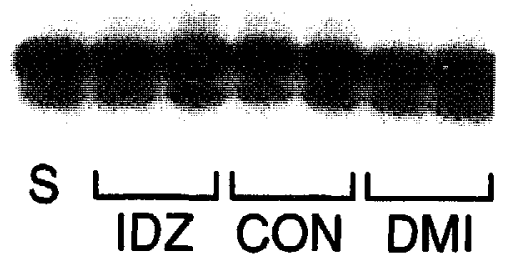

PT

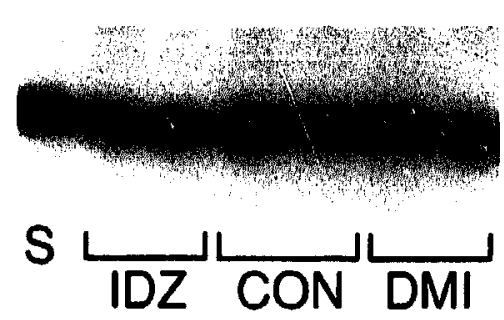

$={ }_{45 \mathrm{kD}}^{52 \mathrm{~K}}$

$-40 \mathrm{kD}$

Figure 10. Representative autoradiograms of immunolabeling of $\mathbf{G} \alpha_{s}, \mathbf{G} \alpha_{i 1 / 2}$, and SDS-PAGE of

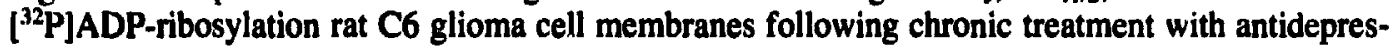
sants. For immunolabeling, tissues were prepared as described in methods section, and subjected to SDS-PAGE and electrophoretic transfer. Immunodetection was performed by polyclonal anti$\mathrm{G} \alpha$ antibodies, and ${ }^{125} \mathrm{l}$-labeled secondary antibody. For ribosylation studies, membranes were ADP-ribosylated in the presence of preactivated toxins and subjected to SDS-PAGE. Quantitation of ${ }^{32} \mathrm{P}$ incorporation was accomplished by densitometric scanning of the autoradiograms. $D M I=$ desipramine; $I D Z=$ idazoxan; $C O N=$ control; $M W=$ molecular weight standards; $C T=$ cholera toxin; $P T=$ pertussis toxin.

being elucidated (Moriarty et al 1990; Wong et al 1992). $G_{o}$ has been implicated in the regulation of pertussis toxin-sensitive phosphoinositide hydrolysis and more recently it has been reported, that distinct splice variants of $\mathrm{G}_{o}$ mediate the muscarinic and somatostatin receptor-induced inhibition of $\mathrm{Ca}^{2+}$ channels (Bertrand et al 1990; Strathmann et al 1990; Kleuss et al 1991; Tsukamoto et al 1991). $G_{2}$ has been demonstrated to mediate hormonal inhibition of cAMP accumulation when transfected into cells (Wong et al 1992). 
Although there is growing evidence that the isozyme $\beta 1$ of phospholipase $C$ is stimulated via toxin-insensitive $G_{q}$ isotypes (Smrcka et al 1991; Taylor et al 1991), the receptoreffector association of $G_{12}$ isotypes remains unknown.

Because a single receptor subtype can couple to multiple $\mathbf{G}$ proteins, and multiple $\mathbf{G}$ proteins can converge to activate or inactivate a single effector (Ross 1989; Taylor 1990; Manji 1992), the $G$ protein-dependent interactions form complex networks. The high degree of complexity generated by the interactions of $\mathbf{G}$ protein-coupled receptors may be one mechanism by which neurons acquire the flexibility for generating the wide range of responses observed in the CNS. This has led to the proposal that $\mathbf{G}$ proteins may be involved in pathways regulating such diverse vegetative functions as mood, appetite, and wakefulness (North 1989), and, by extrapolation, in the molecular mechanisms of action of ADs (Lesch et al 1991a).

In the present series of studies, we have used immunoblotting as well as ELISA techniques with antibodies against $\mathrm{G} \alpha_{s}, \mathrm{G} \alpha_{i}, \mathrm{G} \alpha_{o}$, and $\mathrm{G} \alpha_{q}$, and toxin-catalyzed ADPribosylation, to demonstrate alterations of $\mathrm{G} \alpha$ subunit steady-state concentrations during chronic treatment with various monoamine reuptake blockers and a MAO-A inhibitor. In view of the differing pharmacologic pr files of these drugs (and their metabolites) with respect to receptor binding, monoamine reuptake inhibition, and enzymatic inhibition, in conjunction with the fact that monoamine neurotransmitter systems interact extensively in vivo, it is not surprising that the various ADs exerted distinct patterns of effects. Nevertheless, several interesting, novel common effects have emerged from our studies. All ADs tended to decrease the immunolabeling of $G \alpha_{s}$ in the hippocampus, consistent with the recent report of post-receptor desensitization of hippocampal adenylyl cyclase activity following chronic DMI (Tiong and Richardson 1990), and suggesting a coordinate downregulation of the $\beta$-adrenoceptor- $G_{s}$-adenylyl cyclase complex by ADs (Sugrue 1983; Sulser 1984). In view of the well known hypercortisolemia and activation of the HPA axis observed in a subset of depressed patients (Nemeroff 1987), and the observation that chronic stress may play a role in the development of depression, it is noteworthy that the effects of $\mathrm{ADs}$ on $\mathrm{G} \alpha$, are the opposite of those observed with chronic glucocorticoid administration (Saito et al 1989; Lesch and Lerer 1991). Similarly, all ADs tended to decrease $G \alpha_{i 1 / 2}$ in hippocampus, whereas all the tricyclics (but not the MAOI) tended to increase $\mathrm{G} \alpha_{o}$ in the hippocampus, using immunoblotting or ELISA techniques. Interestingly, the possible involvement of pertussis toxin substrates $\left(G \alpha_{i}, G \alpha_{o}\right)$ in mediating DMI's effects has previously been postulated (Okada et al 1988). Moreover, the opposite effects of the ADs on the levels of $G \alpha_{i}$ and $G \alpha_{o}$ that we have demonstrated also offer an explanation for the seemingly disparate findings of hippocampal 5-HT $\mathrm{HA}_{1 \mathrm{~A}}$ receptormediated signal transduction following chronic ADs using functional, biochemical or electrophysiological measures (Chaput et al 1991; Lesch 1991). In the absence of consistent changes in the density of 5-HT $1 \mathrm{~A}$ receptors (Hensler et al 1991), a TCA-induced increase in the concentration of $\mathrm{G}_{o}$ would account for the enhancement of hippocampal CAl $5-H_{1 A}$-mediated electrophysiological responses, while the reduction in $\mathrm{G}_{i}$ isotypes may underlie the diminished capacity to inhibit adenylyl cyclase activity (Newman et al 1990; Newman et al 1992). Intriguingly, our failure to demonstrate alterations in the levels of $\mathrm{G}_{0}$ following chronic administration of CLG is entirely consistent with the evidence from other laboratories that MAOIs increase 5-HT throughput via presynaptic facilitation of neurotransmitter release (Blier et al 1990).

Another consistent finding to emerge from our studies is the increase in the concentrations of $\mathrm{G} \alpha_{o}$ and decrease in the levels of $\mathrm{G} \alpha_{s}$ in the locus coeruleus (LC) following 
chronic $\mathrm{AD}$ treatment. Following chronic treatment with a variety of $\mathrm{ADs}$ a reduction in the firing rate of LC neurons, and a reduction in the levels of tyrosine hydroxylase (TH) and its mRNA in the LC has been reported (Blier and de Montigny 1985; Nestler et al 1990). The mechanism(s) underlying these effects are unknown, and since they are not observed following chronic clonidine, they are unlikely to be due to increased stimulation of somatodendritic $\alpha_{2}$-receptors. Because the firing rate of LC neurons is dependent on the regulation of $\mathrm{K}^{+}$channels (presumably coupled to $\mathbf{G}_{o}$ ) and is also modulated by cAMP (Aghajanian and Wang 1987; Alreja and Aghajanian 1991), AD-induced increases in $\mathrm{G}_{o}$ and decreases in $\mathrm{G}_{s}$ should, in theory, both decrease the firing of these neurons.

The mechanisms by which ADs modulate steady-state concentrations of $\mathbf{G}$ proteins remain to be elucidated, but may involve alterations in expression, expression of an inactive form, or in posttranslational modification resulting in increased or decreased turnover of the proteins. In this context, $G$ proteins are the targets of a number of posttranslational modifications, several of which are known to modify their functional status. In addition to ADP-ribosylation by bacterial toxins, $G$ protein subunits are also subject to phosphorylation, isoprenylation, myristolation, and methylation (Houslay and Milligan 1990), any of which may alter the turnover of the protein (as has been demonstrated for $\mathrm{G} \alpha_{s}$ following ADP-ribosylation) (Carr et al 1990). Indeed, the results of our cell culture studies do suggest a functional modification of $\mathrm{G}_{s}$ by $A D s$.

Neither DMI nor IDZ was toxic to the C6 cells, consistent with the report that the presence of serum in the medium protects these cells from possible in vitro toxic effects of antidepressants (Fowler and Brannstrom 1990). Both DMI and IDZ produced a significant downregulation of $\beta$-adrenoceptors, accompanied by a reduction in the isoproterenol-stimulated cAMP accumulation. Interestingly, the magnitude of the $\beta$-adrenoceptor downregulation observed in the present study is similar to that induced by a variety of ADs in rat brain (Sulser 1984), and observed in other in vitro AD studies (Honegger et al 1986; Fishman and Finberg 1987; Manji et al 1991). Moreover, similar to what has been reported in rat brain (Turkka et al 1989), the $\beta$-adrenoceptor desensitization was accompanied by a significant increase in the $K_{L} / K_{H}$ ratio for the receptor. The $K_{L} / K_{H}$ ratio reflects the extent to which agonists stabilize the high affinity ternary complex (composed of agonist, receptor, and $\mathrm{G}$ protein, whereby a lower dissociation constant $\left(K_{H}\right)$ favors the ternary complex) and has been demonstrated to strongly correlate with agonist-induced adenylyl cyclase activation (Kent et al 1980). More recent studies have shown, however, that the molecular determinants of the $\beta$-adrenergic receptor involved in the formation of the ternary complex are distinct from those involved in the functional activation of the stimulatory $\mathbf{G}$ protein (Hausdorff et al 1990). In this context, it is interesting to note chronic DMI treatment of rats is reported to decrease the affinity of guanine nucleotides for $\mathrm{G}_{s}$, thereby preventing the breakdown of the high affinity complex and subsequent activation of adenylyl cyclase (Tsuchiya et al 1988), and to inhibit in a dose-dependent manner high affinity GTPase activity in vitro (Yamamoto et al 1990). If ADs do interfere with the binding of guanine nucleotides to $G_{s}$ and the subsequent breakdown of the high affinity ternary complex (Tsuchiya et al 1988), it would explain the dissociation between the two parameters thought to refiect the same coupling phenomenon, namely, the formation of the high affinity ternary complex and stimulation of adenylyl cyclase. This postulated mechanism receives additional support from our results demonstrating that both DMI and IDZ significantly reduced the cholera toxin-catalyzed ${ }^{32} \mathrm{P}$-labeling, without altering the immunolabeling of $\mathbf{G} \alpha_{s}$. Thus, in contrast to the antisera, which recognizes both free and undissociated $\alpha_{s} \beta \gamma$, cholera toxin preferentially labels the dissociated form 
of $\mathrm{G} \alpha_{s}$ (Moss and Vaughan 1991; Manji 1992). The decrease in the cholera toxin labeling in the absence of any alteration in the immunolabeling of $\mathbf{G} \alpha_{s}$ thus supports the notion of a shift towards the undissociated form of $\mathrm{G}_{s}$. The reason(s) for the failure to detect an alteration in the immunolabeling of $\mathbf{G} \alpha_{s}$ or $\mathbf{G} \alpha_{i}$ following $A D s$ in vitro, despite the functional evidence for attenuation of $G_{s}$ function, is presently unclear. It is possible that the decrease in $\mathrm{G} \alpha_{s}$ and $\mathrm{G} \alpha_{i 1 / 2}$ concentrations in vivo require an intact integrated system (or at least presynaptic input); however, more recent in vivo studies have also demonstrated that ADs result in an early "uncoupling" of the $\beta$-receptor from $\mathrm{G}_{s}$, followed by changes in $\mathrm{G}_{s}$ function after chronic ( $>3 \mathrm{wk}$ ) treatment (Okada et al 1986; Tiong and Richardson 1990). Thus, it remains possible that our failure to detect any alterations in the immunolabeling of $\mathrm{G} \alpha_{s}$ or $\mathrm{G} \alpha_{i}$ following in vitro incubation of $\mathrm{C} 6$ cells with either DMI or IDZ was due simply to the relatively short (5 day) incubation period.

One of the major findings of our studies is that at least some of the changes in $\mathbf{G}$ protein $\alpha$ subunit steady-state concentrations during chronic AD treatment may occur at the transcriptional level. We observed a distinct pattern of changes in G $\alpha$ mRNA expression across brain areas during chronic $\mathrm{AD}$ treatment. In analogy to agonist-induced receptor downregulation (presumably by second messenger-induced modulation of transcription rate and of steady-state concentrations of receptor mRNA) as form of feedback regulation at the level of receptor gene expression (Collins et al 1989), persistent receptor desensitization is likely to be associated with a modified functional status of signal transduction mechanisms by homologous and/or heterologous regulation of its $\mathbf{G}$ proteins involving both transcriptional and posttranscriptional components. Our findings provide direct evidence that concentrations of $\mathrm{G} \alpha_{s}$ mRNA and, $v$ a lesser extent, $G \alpha_{i 1 / 2}$ mRNA are increased in several brain regions by selective and noncelective reuptake inhibitors as well as a MAOI which tends to coincide with AD-induced decreases in $\mathbf{G}_{\boldsymbol{s}}$ and $G \alpha_{i 1 / 2}$ protein. At least two mechanisms may be responsible for this apparently noncoordinate regulation of $\mathrm{Ga} \mathrm{mRNA}$ and protein. One possibility is that increased steady-state concentrations of $G \alpha_{s}$ and $G \alpha_{i 1 / 2}$ mRNA reflect a compensatory regulation in response to $A D$-induced modulation of mRNA processing, transport, and translation, or to increased $G \alpha$ protein turnover due to a direct $A D$-dependent inhibition of $G$ protein function. Alternatively, it is possible that ADs exert a direct effect on the regulation of $G \alpha$ gene transcription. Supporting this assumption, it has recently been reported that tricyclic ADs including imipramine and desipramine alter type II glucocorticoid receptor (GR) mRNA levels in rat brain and increase the wctivity of the human GR gene promoter in a transfection model (Peiffer et al 1991; Pepin et al 1992). In contrast to $G \alpha_{s}$ and $\mathrm{G} \alpha_{i / 2}$ mRNA regulation, TCA-induced increases $\mathrm{G} \alpha_{o}$ mRNA expression in conjunction with increased concentrations of $\mathrm{G} \alpha_{o}$ protein in some brain areas appears to reflect a coordinate regulation and further support the hypothesis of a direct effect of ADs at the transcriptional level. Finally, although the physiologic implications remain to be clarified, all $A D s$ consistently increased $G \alpha_{12}$ mRNA expression in the frontal cortex. Hence, regardless of mechanisms, mRNA transcription, processing, transport and translation may be central in the regulation of $G$ protein function and its modulation during long-term administration of drugs with therapeutic potential in a variety of affective disorders.

The investigation of $\mathbf{G}$ protein expression and ultimately $\mathbf{G}$ protein function at the transcriptional level offers an additional advantage since, among $\mathrm{G} \alpha$ isotypes, nucleic sequences exhibit a higher level of diversity than amino acid sequences. This further assists in the differentiation of $\mathrm{G} \alpha$ isotypes and allows the functional dissection of specific 
neuroadaptational changes during $\mathrm{AD}$ treatment. With this rationale in mind, we report the cloning of a reverse transcriptase-PCR-generated rat and human brain $G \alpha_{q}$ and $G \alpha_{12}$ partial cDNA, and application of their antisense [ $\left.{ }^{32} \mathrm{P}\right] \mathrm{CRNA}$ transcripts as probes for the quantitative evaluation of $\mathrm{G} \alpha_{q}$ (several variants most likely resulting from alternate splicing) and $\mathrm{G \alpha}_{12}$ mRNA expression in rat brain by Northern blot analysis and RNase protection assay techniques. Although the PCR-generated $G \alpha_{q}$ and $G \alpha_{12}$ partial cDNA requires verification by isolation of the corresponding sequences from rat and human cDNA libraries, our data indicate that $\mathrm{G} \alpha_{q}$ is highly conserved among mammalian species and humans. We believe that this approach is a critical step toward the elucidation of the function(s) of the as yet enigmatic toxin-insensitive $G_{q}$ and $G_{12}$ class.

$G_{q}$ and possibly $G_{12}$ proteins, which appear to be abundantly expressed in rodent and human brain, are prime candidates as mediators of phosphoinositide cycle activation by multiple phospholipase $\mathrm{C}$ isozymes. Our finding of an increase in $\mathrm{G} \alpha_{q}$ and $G \alpha_{12} m R N A$ by chronic 5 -HT reuptake inhibition in neostriatum and frontal cortex, is striking since phospholipase-associated second messengers (inositol polyphosphates, diacylglycerol, and $\mathrm{Ca}^{2+}$ ) are known to induce mitogenesis in non-neuronal cells (involving regulation of gene expression by protein kinases-dependent transcriptional activation of DNA regulatory elements) and neuroadaptational plasticity in postmitotic neurons. Moreover, 5 $\mathrm{HT}$ is a potent mitogenic (with $5-\mathrm{HT}_{1 \mathrm{C}}$ and $5-\mathrm{HT}_{2}$ receptors playing a central role in cellular transformation) (Seuwen et al 1988; Julius 1991). Since the $G_{q}$ and $G_{12}$ class of $G$ proteins (among others) may represent novel targets for psychotropic drugs, studies are currently underway in our laboratory to screen human cDNA and genomic libraries in order to elucidate the complete sequence of $G \alpha_{q}$ and $G \alpha_{12}$ and thereby obtain insight into the regulation of their genes. Using PCR and somatic cell hybrids we recently determined the assignment of the human $\mathrm{G} \alpha_{q}$ gene to the human chromosome 9 (Polymeropoulos et al 1992).

\section{Conclusions}

Signal transduction through specific receptors plays a central role in neuronal activation. Understanding the mechanisms by which the binding of a neurotransmitter to a receptor at the cell surface is translated into a biochemical (and ultimately a physiologic) effect has clearly come a long way in the past decade. In particular, there has been dramatic progress in defining both the structure and the function of the signal-transducing $\mathbf{G}$ protein family, the diversity of which continues to grow. Cross-species PCR-mediated generation of cRNA probes utilized in Northern blot and RNase protection techniques facilitates the differential evaluation and quantitation of $G$ protein $\alpha$ subunit expression during chronic psychotropic drug treatment. The observations that the amount of $\mathbf{G}$ protein subunits and their transcriptional regulation in a given tissue is not a static entity, but is under the influence of physiological, pathophysiological and pharmacologic perturbations, have clear implications not only for research into the etiology of various psychiatric disorders but also for the development of innovative treatment strategies. Alterations in $\mathbf{G}$ protein function have now been identified in the etiology/pathophysiology of a variety of medical diseases. Through an improved understanding of the modulation of signal transduction pathways in the brain, it may be possible to identify the molecular factors underlying both the predisposition to and the pathogenesis of various major psychiatric illnesses. These molecular abnormalities may be subtle, perhaps at the level of regulation of $G$ protein function in response to neurotransmitter changes, to modification in concentrations 
of so-called "permissive hormones," and to environmental events and stressors. Finally, given the increasing evidence that the currently available psychotropic drugs affect $\mathbf{G}$ proteins, the development of novel drugs with $\mathbf{G}$ proteins as primary targets remains an attractive prospect for the future.

The authors thank D.L. Murphy, W.Z. Potter, C.S. Aulakh, G. Chen, J.L. Hill, C.L. Hough, B.M. Martin, T.J. Tolliver, and B.L. Wolozin, for their valuable assistance and discussions of the various studies.

\section{References}

Aghajanian GK, Wang YY (1987): Common $\alpha_{2}$ and opiate effector mechanisms in the locus coeruleus: intracellular studies in brain slices. Neuropharmacology 26:793-799.

Alreja M, Aghajanian GK (1991): Pacemaker activity of locus coeruleus neurons: whole cell recordings in brain slices show dependence on CAMP and protein kinase A. Brain Res 556:339343.

Aulakh CS, Wozniak KM, Haas M, et al. (1988); Food intake, neuroendocrine and temperature effects of 8-OHDPAT in the rat. Eur J Pharmacol 146:253-259.

Avissar S, Schreiber G, Danon A, Belmaker RH (1988): Lithium inhibits adrenergic and cholinergic increases in GTP binding in rat cortex. Nature 331:440-442.

Avissar S, Schreiber G (1989): Muscarinic receptor subclassification and G-proteins: Significance for lithium action in affective disorders and for the treatment of the extrapyramidal side effects of neuroleptics. Biol Psychiatry 26:113-130.

Avissar S, Schreiber G (1992): The involvement of guanine nucleotide binding proteins in the pathogenesis and treatment of affective disorders. Biol Psychiatry 31:435-459.

Bertrand P, Sanford J, Rudolph U, Codina J. Bimbaumer L (1990): At least three alternatively spliced mRNAs encoding two $\alpha$ subunits of the $G_{o}$ GTP-binding protein can be expressed in a single tissue. $J$ Biol Chemistry 265:18576-18580.

Birnbaumer L (1990): G proteins in signal transduction. Ann Rev Pharmacol Toxicol 30:675-705.

Blier P, de Montigny C (1985): Serotonergic but not noradrenergic neurons in rat central nervous system adapt to long-term treatment with monoamine oxidase inhibitors. Neuroscicnce 16:949956.

Blier P. De Montigny C. Chaput Y (1990): A role for the serotonin system in the mechanisms of action of antidepressant treatments: preclinical evidence. J Clin Psychiatry 51S:14-20.

Carr C, Loney C, Unson C, Knowler J, Milligan G (1990): Chronic exposure of rat glioma C6 cells to cholera toxin induces loss of the $\alpha$-subunit of the stimulatory guanine nucleotide-binding protein $\left(G_{s}\right)$. Eur J Pharmacol Mol Pharmacol Sec 188:203-209.

Chaput Y, de Montigny C, Blier P (1991): Presynaptic and postsynaptic modifications of the serotonin system by long-term administration of antidepressant treatments: an in vivo electrophysiologic study in the rat. Neuropsycholpharmacology 5:219-224.

Chomczynski P, Sacchi N (1987): Single-step method of RNA isolation by acid guanidinium thiocyanate-phenol chloroform extraction. Anal Biochem 162:156-159.

Collins S, Bouvier M, Bolanowski MA, Caron M, Lefkowitz RJ (1989): cAMP stimulates transcription of the $\beta_{2}$-adrenergic receptor gene in response to short-term agonist exposure. Proc Natl Acad Sci USA 86:4853-4857.

Fishman PH, Finberg JP (1987): Effect of the tricyclic antidepressant desipramine on $\beta$-adrenergic receptors in cultured rat glioma $C 6$ cells. $J$ Neurochem 49:282-9.

Fowler CJ, Brannstrom G (1990): Reduction in $\beta$-adrenoceptor density in cultured rat glioma C6 cells after incubation with antidepressants is dependent upon the culturing conditions used. $J$ Neurochem 55:245-251.

Gilman AG (1989): The Albert Lasker Medical Award. G proteins and regulation of adenylyl cyclase. JAMA 262:1819-25. 
Grahame-Smith DG (1988). Neuropharmacological adaptive effects in the action of antidepressant drugs, ECT and lithium. New Concepts in depression. Cambridge: Macmillan, 1-14.

Hausdorff WP, Hnatowich M, O'Dowd FO, Caron MG, Lefkowitz RJ (1990): A mutation of the $\boldsymbol{\beta}_{2}$-adrenergic receptor impairs agonist activation of adenylyl cyclase without affecting high affinity agonist binding. Distinct molecular determinants of the receptor are involved in physical coupling to and functional activation of $\mathbf{G}_{s} . J$ Biol Chem 265:1388-1394.

Hensler JG, Kovachich GB, Frazer A (1991): A quantitative autoradiography study of serotonin ${ }_{1 A}$ receptor regulation: effect of 5,7-dihydroxytryptamine and antidepressant treatments. Neuropsychopharmacology 4:131-144.

Honegger UE, Disler B, Wiesmann UN (1986): Chronic exposure of human cells in culture to the tricyclic antidepressant desipramine reduces the number of $\beta$-adrenoceptors. Biochem Pharmacol 35:1899-902.

Hough $C$, Chuang DM (1990): Differential down-regulation of $\beta_{1}$ - and $\boldsymbol{\beta}_{2}$-adrenergic receptor mRNA in $\mathrm{C}_{6}$ glioma cells. Biochem Biophys Res Commun 170:46-52.

Houslay MD, Milligan G (1990): G-proteins as mediators of cellular signalling processes. New York: Wiley.

Julius D (1991): Molecular biology of serotonin receptors. Ann Rev Neurosci 14:335-360.

Kent R, Delean A, Lefkowitz R (1980): A quantitative analysis of beta adrenergic receptor interactions: resolution of high and low affinity states of the receptor by computer modelling of ligand binding sites. Mol Pharmacol 17:14-20.

Kleuss C, Hescheler J, Ewel C, et al (1991). Assignment of G-protein subtypes to specific receptors inducing inhibition of calcium currents. Nature 353:43-48.

Kurose H, Regan, JW, Caron MG, Lefkowitz RJ (1991): Functional interaction of recombinant $\alpha_{2}$ adrenergic receptor subtypes and $G$ proteins in reconstituted phospholipid vesicles. Biochemistry 30:3335-3341.

Lesch KP (1991): 5-HT 1 receptor responsivity in anxiety disorders and depression. Prog NeuroPsychopharmacol Biol Psychiatry 15:723-733.

Lesch KP, Aulakh CS, Tolliver TJ, Hill JL, Murphy DL (1991a): Regulation of G proteins by chronic antidepressant drug treatment in rat brain: tricyclics but not clorgyline increase $\mathbf{G}_{o} \alpha$ subunits. Eur J Pharmacol Mol Pharmacol Sec 207:361-364.

Lesch KP, Aulakh CS, Tolliver TJ, et al (1991b): Differential effects of long-term lithium and carbamazepine administration on $G_{s a}$ and $G_{i \alpha}$ protein in rat brain. Eur $J$ Pharmacol Mol Pharmacol 207:355-359.

Lesch KP, Hoh A, Osterheider M, Schulte HM, Muller T (1991c): Long-term fluoxetine treatment decreases 5-HT ${ }_{1 A}$ receptor responsivity in obsessive-compulsive disorder. Psychopharmacology 105:415-420.

Lesch KP, Lerer B (1991): The 5-HT receptor-G-protein-effector system complex in depression: I. Effect of glucocorticoids. J Neural Transm 84:3-18.

Liu FY, Albert PR (1991): Cell-specific signaling of the 5-HT1A receptor. J Biol Chemistry 267:23689-23697.

Manji HK (1992): G proteins: implications for psychiatry. Am J Psychiatry 149:746-760.

Manji HK, Chen G, Bitran JA, Gusovsky F, Potter WZ (1991): Chronic exposure of C6 glioma cells to desipramine desensitizes $\beta$-adrenoceptors, but increases $K_{l} / K_{h}$ ratio. Eur $J$ Pharmacol Mol Pharmacol Sec 206:159-162.

Matesic DF, Manning DR, Luthin GR (1991): Tissue-dependent association of muscarinic acetylcholine receptors with guanine nucleotide-biding regulatory proteins. Mol Pharmacol 40:347353.

Michell RH, Drummond AH, Downes CP (1989): Inositol lipids in cell signalling. London: Academic Press.

Moriarty TM, Padrell E, Carty DJ, et al (1990): $G_{o}$ protein as signal transducer in the pertussis toxin-sensitive phosphatidylinositol pathway. Nature 343:79-82. 
Moss J, Vaughan M, eds (1991): ADP-ribosylating toxins and $G$ proteins: insights into signal transduction. Washington DC: American Society for Microbiology.

Murphy DL, Lesch KP, Aulakh CS, Pigott TA (1991): Serotonin-selective arylpiperazines with neuroendocrinc, behavioral, temperature, and cardiovascular effects in humans. Pharmacol Rev 43:527-552.

Nemeroff CB (1987): Handbook of clinical psychoneuroendocrinology. New York, Guilford Press.

Nestler EJ, Terwilliger RZ, Walker JR, Sevarino KA, Duman RS (1990): Chronic cocaine treatment decreases levels of the $G$ protein subunits $G_{i \alpha}$ and $G_{\alpha \alpha}$ in discrete regions of rat brain. $J$ Neurochem 55:1079-82.

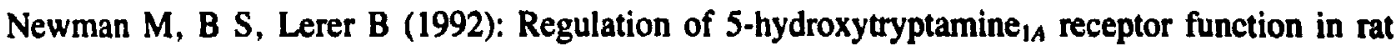
hippocampus by short- and long-term administration of 5-hydroxytryptamine ${ }_{1 A}$ agonist and antidepressants. $J$ Pharmacol Exp Ther 260:16-20.

Newman ME, Drummer D, Lerer B (1990): Single and combined effects of desipramine and lithium on serotonergic receptor number and second messenger function in rat brain. $J$ Pharmacol Exp Ther 252:826-831.

North RA (1989): Twelfth Gaddum memorial lecture. Drug receptors and the inhibition of nerve cells. Br J Pharmacol 98:13-28.

Okada, Tokumitsu Y, Ui $M$ (1988): Possible involvement of pertussis toxin substrates $\left(G_{i}, G_{a}\right)$ in desipramine-induced refractoriness of adenylate cyclase in cerebral cortices of rats. $J$ Neurochem 51:194-199.

Okada F, Tokumitsu Y, Ui M (1986): Desensitization of beta-adrenergic receptor-coupled adenylate cyclase in cerebral cortex after in vivo treatment of rats with desipramine. J Neurochem 47:4549.

Peiffer A, Veilleux S, Barden N (1991): Antidepressant and other centrally acting drugs regulate glucocorticoid receptor messenger RNA levels in rat brain. Psychoneuroendocrinology 16:505515.

Pepin MC, Govindan MV, Barden N (1992): Increased glucocorticoid receptor gene promoter activity after antidepressant treatment. Mol Pharmacol 41:1016-1022.

Polymeropoulos MH, Torres R, Lesch KP, Merril CR (1992): Mapping of the human $G \alpha_{a}$ gene on human chromosome 9. Genomics, in press.

Ross EM (1989): Signal sorting and amplification through $\mathbf{G}$ protein-coupled receptors. Neuron 3:141-52.

Saito N, Guitart X, Hayward M, et al (1989): Corticosterone differentially regulates the expression of $G_{s a}$ and $G_{i a}$ messenger RNA and protein in rat curebral cortex. Proc Natl Acad Sci USA 86:3906-3910.

Seuwen K, Magnaldo I, Pouyssegu J (1988): Serotonin stimulates DNA synthesis in fibroblasts acting through 5-HT 1 receptors coupled to a $G_{-}$-protein. Nature 335:254-256.

Simon MI, Strathmann MP, Gautam N (1991): Diversity of G proteins in signal transduction. Science 252:802-808.

Smrcka AV, Helpler JR, Brown KO, Sternweis PC (1991): Regulation of polyphosphoinositidespecific phospholipase $C$ activity by purified $G_{q}$. Science $251: 804-807$.

Spiegel AM, Simonds WF, Jones TL, Goldsmith PK, Unson CG (1990): Antibodies against synthetic peptides as probes of $G$ protein structure and function. Soc Gen Physiolo Ser 45:18595.

Strathmann MP, Simon MI (1990): G protein diversity: a distinct class of $\alpha$ subunits is present in vertebrates and invertebrates. Proc Natl Acad Sci USA 87:9113-9117.

Strathmann MP, Simon MI (1991): Ga12 and Ga13 subunits define a fourth class of $G$ protein $\alpha$ subunits. Proc Natl Acad Sci USA 88:5582-5586.

Strathmann MP, Wilkie TM, Simon MI (1990): Alternative splicing produces transcripts encoding two forms of the $\alpha$ subunit of GTP-binding protein $G_{o}$. Proc Nati Acad Sci USA 87:6477-6481.

Sugnue MF (1983): Chronic antidepressant therapy and associated changes in central monoaminergic function. Pharmacol Ther 21:1-37. 
Sulser F (1984): Antidepressant treatments and regulation of norepinephrine-receptor-coupled adenylate cyclase systems in brain. Adv Biochem Psychopharmacol 39:249-61.

Taylor CW (1990): The role of $G$ proteins in transmembrane signalling. Biochem $J$ 272:1-13.

Taylor SJ, Chae HZ, Rhee SG, H EJ (1991): Activation of the $\beta 1$ isozyme of phospholipase C by $\alpha$ subunits of the $G_{q}$ class of $G$ proteins. Nature 350:516-519.

Tiong AHK, Richardson JS (1990): $\beta$-Adrenoceptor and post-receptor components show different rates of desensitization to desipramine. Eur J Pharmacol Mol Pharmol Sec 188:411-415.

Tsuchiya F, Ikdea, H, Hatta Y, Saito T (1988): Effects of desipramine administration on receptor adenylate cyclase coupling in rat cerebral cortex. Jpn J Psychiatr Neurol 42:858-860.

Tsukamoto T, Toyoma R, Itoh H, Kosaza T, Matsuoka M, Kaziro Y (1991): Structure of the human gene and two rat CDNAs encoding the $\alpha$ chain of GTP-biding regulatory protein $\mathrm{G}_{0}$ : two different mRNAs are generated by alternative splicing. Proc Nall Acad Sci USA 88:29742978.

Turkka J, Gurguis G, Potter WZ, Linnoila M (1989): Ten day administration of desipramine produces an increase in $K_{\nu} / K_{H}$ for $\beta$-receptors in rat hippocampus. Eur $J$ Pharmacol 167:8793.

Wong YH, Conklin BR, Bourne HR (1992): $G_{z}$-mediated hormonal inhibition of cyclic AMP accumulation. Science 255:339-342.

Wozniak KM, Aulakh CS, Hill JL, Murphy DL (1988): The effect of 8-OH-DPAT on temperature in the rat and its modification by chronic antidepressant treatments. Pharmacol Biochem Behav 30:451-456.

Yamamoto H, Kagaya A, Kuroda Y, Mikuni M, Takahashi K (1990): Effect of antidepressants on the GTP binding sites in rat brain homogenates. Jpn J Psychiatr Neurol 44:133-136. 